\title{
In Planta and Soil Quantification of Fusarium oxysporum f. sp. ciceris and Evaluation of Fusarium Wilt Resistance in Chickpea with a Newly Developed Quantitative Polymerase Chain Reaction Assay
}

\author{
Daniel Jiménez-Fernández, Miguel Montes-Borrego, Rafael M. Jiménez-Díaz, \\ Juan A. Navas-Cortés, and Blanca B. Landa
}

First and third authors: College of Agriculture and Forestry, University of Córdoba, Edificio C-4 'Celestino Mutis', Campus de Rabanales, Ctra. Madrid-Cádiz, km 396, 14071 Córdoba, Spain; and second, fourth, and fifth authors: Institute of Sustainable Agriculture (IAS), Spanish National Research Council (CSIC), Alameda del Obispo S/N, P.O. Box 4084, 14080 Córdoba, Spain. Accepted for publication 22 September 2010.

\begin{abstract}
Jiménez-Fernández, D., Montes-Borrego, M., Jiménez-Díaz, R. M., Navas-Cortés, J. A., and Landa, B. B. 2011. In planta and soil quantification of Fusarium oxysporum f. sp. ciceris and evaluation of Fusarium wilt resistance in chickpea with a newly developed quantitative polymerase chain reaction assay. Phytopathology 101:250-262.

Fusarium wilt of chickpea caused by Fusarium oxysporum f. sp. ciceris can be managed by risk assessment and use of resistant cultivars. A reliable method for the detection and quantification of $F$. oxysporum $\mathrm{f}$. sp. ciceris in soil and chickpea tissues would contribute much to implementation of those disease management strategies. In this study, we developed a real-time quantitative polymerase chain reaction (q-PCR)

with several races of the pathogen. Moreover, the q-PCR protocol clearly differentiated susceptible from resistant chickpea reactions to the pathogen at 15 days after sowing in artificially infested soil, as well as the degree of virulence between two F. oxysporum f. sp. ciceris races. Also, the protocol detected early asymptomatic root infections and distinguished significant differences in the level of resistance of 12 chickpea cultivars that grew in that same field plot infested with several races of the pathogen. Use of this protocol for fast, reliable, and cost-effective quantification of $F$. oxysporum $\mathrm{f}$. sp. ciceris in asymptomatic chickpea tissues at early stages of the infection process can be of great value for chickpea breeders and for epidemiological studies in growth chambers, greenhouses and field-scale plots.
\end{abstract} protocol that allows quantifying $F$. oxysporum $\mathrm{f}$. sp. ciceris DNA down to $1 \mathrm{pg}$ in soil, as well as in the plant root and stem. Use of the q-PCR protocol allowed quantifying as low as 45 colony forming units of $F$. oxysporum f. sp. ciceris per gram of dry soil from a field plot infested
Additional keywords: Cicer arietinum, complete resistance, molecular markers, race-specific resistance, SYBR green.
Chickpea (Cicer arietinum L.) is one of the world's most important pulse crops with dry beans (Phaseolus vulgaris L.) and dry peas (Pisum sativum L.) (10). It is not only a source of human food and animal feed but it also helps in the management of soil fertility, particularly in dry lands and the semiarid tropics where chickpea production is concentrated (54). Fusarium wilt caused by Fusarium oxysporum Schlechtend. Fr. f. sp. ciceris (Padwick) Matuo \& K. Sato is the most important soilborne disease limiting chickpea production worldwide, but mainly in the Mediterranean Basin and the Indian subcontinent $(17,56)$. Annual yield losses from this disease have been estimated to range from 10 to $15 \%$ $(17,56)$. However, Fusarium wilt epidemics can be devastating to individual crops and cause $100 \%$ loss under disease-favorable conditions $(13,40,41)$. In particular, disease attacks are devastating if they occur when the crop is under heat and water stresses during the reproductive and seed filling stages $(5,31,41,55)$.

F. oxysporum f. sp. ciceris exhibits significant pathogenic variability. Eight races of the pathogen (namely races $0,1 \mathrm{~A}, 1 \mathrm{~B} / \mathrm{C}, 2$, $3,4,5$, and 6) have been described to date $(7,14,18,19)$, which can be grouped into the wilting and yellowing pathotypes based on the disease symptoms they induce in pathogenicity tests (56). The yellowing pathotype induces progressive foliar yellowing

Corresponding author: B. B. Landa; E-mail address: blanca.landa @ias.csic.es

First and second authors have contributed equally to this research.

doi:10.1094/PHYTO-07-10-0190

(c) 2011 The American Phytopathological Society with vascular discoloration, followed by plant death within 40 days of inoculation. The wilting pathotype induces severe chlorosis and flaccidity, vascular discoloration, and plant death within 20 days after inoculation. Races 0 and $1 \mathrm{~B} / \mathrm{C}$ are of the yellowing pathotype and are less virulent than races $1 \mathrm{~A}$ through 6 that belong to the wilting pathotype $(18,22)$. This difference in virulence is further indicated by differences in the amount of inoculum needed to cause severe disease in a chickpea cultivar $(30,39,42)$. Races 2 and 3 have been reported in Ethiopia, India, and Turkey $(8,14$, $17,53)$, whereas race 4 have only been reported in Ethiopia and India $(14,17,53)$. Races $0,1 \mathrm{~B} / \mathrm{C}, 5$, and 6 are found mainly in the Mediterranean Basin and the United States in California (13,18, 22,23). Race $1 \mathrm{~A}$ has been reported in the Indian subcontinent (14), California, and the Mediterranean Basin (18,22,23).

Resistant cultivars are one of the few and the most effective means for managing Fusarium wilt of chickpeas $(20,31,33)$, but their deployment has not been extensive because of undesirable agronomic characteristics in some developed cultivars. Furthermore, the high pathogenic variability in $F$. oxysporum $\mathrm{f}$. sp. ciceris populations may limit the effectiveness and extensive use of available resistance $(14,20,21)$. Sources of resistance against $F$. oxysporum f. sp. ciceris have been identified $(51,52)$ and exploited in several chickpea breeding programs $(18,21,45,51,52)$ and a fair number of resistant chickpea germplasm lines operative against specific races of the pathogen have been developed. Consequently, adequate characterization of the resistance of chickpea lines and cultivars to specific races of $F$. oxysporum f. sp. ciceris is essential for resistance deployment. 
In the absence of agronomically and/or commercially suitable resistant cultivars, prediction of disease risk potential in a geographic area based on assessment of pathogen race and inoculum density thresholds in soil and susceptibility of cultivars can be of use for the management of Fusarium wilt in chickpeas (42). For instance, advancing the sowing date of moderately susceptible cultivars from early spring to early winter can contribute to control of the disease in Mediterranean environments; but these benefits can be overridden if high inoculum density or a highly virulent race of the pathogen prevails in soil $(31,40)$.

While $F$. oxysporum f. sp. ciceris isolates can be identified or assigned to pathogenic races by means of polymerase chain reaction (PCR)-based assays $(11,22,23,26,27)$, the characterization of resistance reactions in chickpea germplasm has remained based on conventional and laborious pathogenicity tests. This method of resistance screening is conceptually simple but costly in time (50 to 60 days), facilities, and resources $(18,21,33,51,56)$. Furthermore, the disease reaction in chickpea genotypes during biological pathotyping assays can be influenced by several factors, including soil moisture, inoculum density of the pathogen $(12,30,32,39,42)$, and temperature $(30,33,42)$. Consequently, lack of correct adjustment for these sources of variability may give rise to misleading identification of races of $F$. oxysporum $\mathrm{f}$. sp. ciceris or resistance assessment in chickpea genotypes. Therefore, there is a need for new, improved methods for the rapid, reliable, and reproducible identification and quantification of $F$. oxysporum $\mathrm{f}$. sp. ciceris races in plant roots and stem that provide evidence of vascular infection and facilitate assessment of resistance reactions of chickpea germplasm. Moreover, these methods would be of additional use for the management of the disease if they would provide detection and quantification of pathogen inoculum in soil and thus help in the prediction of disease risk.

Quantitative-PCR (q-PCR) can be a useful tool for achieving the above mentioned challenges in the management of Fusarium wilt of chickpeas. For example, use of q-PCR assays have allowed the accurate and culture-independent quantification of a variety of soil- or plant-associated microorganisms, including plant pathogens from plant tissues, seeds, and soils (reviewed in 48,50). In previous studies, several PCR-based protocols were developed for the characterization of $F$. oxysporum f. sp. ciceris, its pathotypes, and some of the eight described pathogenic races $(11,22,23$, $26,27)$. While some of these protocols are of use for in planta and soil detection $(11,26,27)$, none of them allow for quantifying the pathogen in soil or for estimating the degree of infection in the plant. Overcoming those limitations by means of a quantitative and sensitive PCR method would be of importance for epidemiological studies, quarantine, and disease management as mentioned above. In particular, such a method would be of great value to (i) discriminate between resistant and tolerant reactions of chickpea germplasm to $F$. oxysporum $\mathrm{f}$. sp. ciceris races by quantifying the pathogen in symptomatic and asymptomatic infections; (ii) accurately assess disease reaction by correlating the amount of pathogen in infected plant tissues with the amount of disease developed in resistant/tolerant germplasm and/or after applying other disease control measures (e.g., biological, chemical, or physical), and (iii) avoid the use of high risk soils by selecting those with lowest amount of inoculum of the pathogen.

Consequently, the aim of the present research was to develop a q-PCR protocol that could selectively discriminate isolates of any of the eight $F$. oxysporum f. sp. ciceris races from nonpathogenic $F$. oxysporum from chickpea, other $F$. oxysporum formae speciales, and Fusarium spp., while at the same time allowing quantification of all pathogen races in plant tissues and soil.

\section{MATERIALS AND METHODS}

Fungal isolates and culture conditions. A collection of 115 Fusarium isolates was used in this study (Table 1), of which 50 were representative of different formae speciales of $F$. oxysporum including ciceris (42 isolates), lycopersici (one), melonis (one), niveum (one), phaseoli (one), and pisi (four), and six were nonpathogenic $F$. oxysporum isolates. The remaining 59 Fusarium spp. isolates were obtained from the Fusarium spp. extype collection from the Department of Plant Pathology, Kansas State University, Manhattan, KS. These latter isolates were representative of Fusarium sections Discolor, Elegans, Gibbosum, Lateritium, Liseola, Martiella, Roseum, Spicarioides, and Sporotrichiella (34).

The 42 F. oxysporum f. sp. ciceris isolates were of diverse geographic origin and representative of races described to date, namely $0,1 \mathrm{~A}, 1 \mathrm{~B} / \mathrm{C}, 2,3,4,5$, and 6 ; The six nonpathogenic isolates of $F$. oxysporum were obtained from roots of healthy chickpea plants and were shown to be nonpathogenic to chickpea (Table 1). All isolates were stored in sterile soil tubes at $4^{\circ} \mathrm{C}$, and in $35 \%$ sterile glycerol in distilled water at $-80^{\circ} \mathrm{C}$ for long-term storage.

Active cultures of isolates were obtained by placing small aliquots of the soil culture onto a plate of fresh potato dextrose agar (PDA) (Difco Laboratories, Detroit, MI) and incubating for 4 days at $25^{\circ} \mathrm{C}$ and a 12 -h photoperiod of fluorescent and nearUV light at $36 \mu \mathrm{E} \mathrm{m}^{-2} \mathrm{~s}^{-1}$. For fungal DNA extraction, a small piece of mycelium from actively growing cultures of Fusarium spp. isolates were placed onto a film of sterile cellophane layered over a plate of PDA and incubated for 5 to 7 days as described previously (33). Then, mycelia growing over the cellophane surface were scraped directly with a sterile scalpel, lyophilized, and stored at $-20^{\circ} \mathrm{C}$ until used.

Chickpea plant material. Chickpea cvs. 12071/10054 (PV-1), PV-60, BG-212, P-2245, ICCV-2, UC-15, JG-62, CA334.20.4, ICC14216, PV61, WR-315, and CPS-1 were used in the study. These cultivars show differential resistance reaction to infection by F. oxysporum f. sp. ciceris races (Table 2) (18). Different numbers of chickpea cultivars and tissue types were used for each experiment. For optimizing the newly developed q-PCR protocol, plant DNA was extracted from root and stem pieces sampled from 30-day-old 'PV60' plants grown in sterile sand in a growth chamber adjusted to $25 \pm 2{ }^{\circ} \mathrm{C}$ and 60 to $90 \%$ relative humidity with a 14-h photoperiod of fluorescent light at $360 \mu \mathrm{E} \mathrm{m} \mathrm{m}^{-2} \mathrm{~s}^{-1}$. The tissues were washed under running tap water, surfacedisinfested in $0.5 \% \mathrm{NaOCl}$ for $1.5 \mathrm{~min}$, dried between sterile filter paper sheets, lyophilized, ground, and stored at $-20^{\circ} \mathrm{C}$ until used. For resistance screening using the q-PCR protocol, total genomic DNA was extracted directly from frozen stem and root tissues of 'P-2245' and 'JG-62' plants (described below). For the field experiment, the 12 chickpea cultivars referred to above were used and DNA was extracted from lyophilized, ground root tissue (described below).

DNA extraction and quantification, and development of DNA standard curves. DNA was extracted from $50 \mathrm{mg}$ of lyophilized or $100 \mathrm{mg}$ of fresh plant tissues (according to experiments) or $50 \mathrm{mg}$ of lyophilized fungal mycelium using the GSpinTM IIp Plant Genomic DNA extraction kit (Intron Biotechnology, Korea) and the Fast-Prep FP-120 system (MP Biomedicals, Illkirch, France), according to Landa et al. (29). DNA was extracted from 250-mg soil samples using the FP-120 system running at $5.0 \mathrm{~m} / \mathrm{s}$ for $40 \mathrm{~s}$ combined with the use of the MoBio Ultraclean soil DNA isolation kit (MoBio Laboratories Inc., Carlsbad, CA) according to manufacturer's instructions.

DNA quality was assessed by gel electrophoresis and ethidium bromide staining. All DNA samples were accurately quantified using the Quant-iT DNA Assay Kit Broad Range fluorometric assay (Molecular Probes Inc., Leiden, The Netherlands) and a Tecan Safire fluorospectrometer (Tecan Spain, Barcelona, Spain) (29). Special care was taken to obtain accurate concentrations of pathogen and host DNAs by quantifying each DNA sample in triplicate, in two independent microplates. As an internal control 
of DNA quantification, DNA samples of known concentration were included in each quantification plate. DNA was diluted with sterile, ultrapure water (SUW) as appropriate to get a total DNA concentration ranging from 0 to $10 \mathrm{ng} / \mu \mathrm{l}$.

DNA standard curves for q-PCR assays were obtained from 10 -fold dilutions of $F$. oxysporum f. sp. ciceris isolate Foc-9605 (Table 1). For this purpose, fungal DNA (10 $\mathrm{ng} / \mu \mathrm{l})$ from the isolate was serially diluted $\left(1: 1,1: 10,1: 10^{2}, 1: 10^{3}, 1: 10^{4}\right.$, and $\left.1: 10^{5}\right)$ in SUW (W/Foc-9605) as well as in a fixed background of plant DNA (10 ng/ $\mu$ l) extracted from stems (CS/Foc-9605) and roots (CR/Foc-9605) of 'PV-60' chickpeas or from an artificial soil mixture (SM/Foc-9605). This artificial soil mixture was previously demonstrated to be free of $F$. oxysporum $\mathrm{f}$. sp. ciceris by means of a specific PCR assay (see below). Each standard curve always included plant or DNA extracted from soil alone and/or no template DNA as negative controls. Two independent standard curves were obtained using independent plant, soil, and pathogen DNA sources.

Design of primers and development of an $F$. oxysporum $f$. sp. ciceris-specific PCR protocol. Two sets of primer pairs, namely FOCP1 and FOCP2, were designed to specifically amplify an internal portion of a $1.5-\mathrm{kb}$ sequence characterized amplified region (SCAR)-specific sequence of $F$. oxysporum $\mathrm{f}$. sp. ciceris (AF492451; 22) using Bionumerics 6.0 software (Applied

TABLE 1. Isolates of Fusarium spp. characterized in this study by polymerase chain reaction (PCR) assays using FOCP1, FOCP2 primer pairs, with reference number, geographic origin, and race classification

\begin{tabular}{|c|c|c|}
\hline Fusarium oxysporum ${ }^{\mathrm{a}}$ & Geographic origin $^{\mathrm{b}}$ & Other Fusarium spp. ${ }^{\mathrm{c}}$ \\
\hline \multirow{2}{*}{\multicolumn{2}{|c|}{$\begin{array}{l}\text { F. oxysporum f. sp. ciceris } \\
\text { Race } 0\end{array}$}} & F. acuminatum 11442 \\
\hline & & F. acutatum 10769 \\
\hline Foc-7802, -7952, -8207, -9032, - 91100 & Spain & F. armeniacum 11623 \\
\hline Foc-cc62R, -cc63K, -cc22C & Israel & F. anthophilum 11560 \\
\hline \multicolumn{2}{|l|}{ Race $1 \mathrm{~B} / \mathrm{C}$} & F. avenaceum 11440 \\
\hline Foc-USA 3-1JG-62, -1987-W-17 & United States & F. babinda 11478 \\
\hline Foc-9602 & Tunisia & F. begoniae 10767 \\
\hline \multicolumn{2}{|l|}{ Race $1 \mathrm{~A}$} & F. chlamydosporum 11397 \\
\hline Foc-7989 & India & F. circinatum $10766, \mathrm{H}-10847, \mathrm{H}-10850$ \\
\hline Foc-9166 & Morocco & F. compactum 11624 \\
\hline Foc-9168 & & F. concentricum 10765 \\
\hline Foc-8272 & Spain & F. crookwellense 11451 \\
\hline Foc-9027 PV1 & & F. culmorum 11427 \\
\hline \multicolumn{2}{|l|}{ Race 2} & F. decemcellulare 11411 \\
\hline Foc- $8607,-1992 \mathrm{R} 4 \mathrm{~N}$ & India & F. guttiforme 10764 \\
\hline \multicolumn{2}{|l|}{ Race 5} & F. lactis 10757 \\
\hline Foc-8012, $-8508,-8408$ & Spain & F. lateritium 11403 \\
\hline Foc-U SA1-1JG62, -USA W6-1 & United States & F. longipes 11428 \\
\hline \multicolumn{2}{|l|}{ Race 6} & F. nelsonii 11564 \\
\hline Foc- $8905,-8924$ & Spain & F. nisikadoi 10758 \\
\hline Foc-9170, -9164 & Morocco & F. nygamai 5111 \\
\hline Foc-Tonini & United States & F. phyllophilum 10768 \\
\hline Foc-9620, -9622, -9628 & Israel & F. poae 11470 \\
\hline F. oxysporum f. sp. lycopersici Fol-325-3 & Unknown & F. polyphialidicum 11414 \\
\hline F. oxysporum f. sp. melonis Fom-9016 & Unknown & F. proliferatum $11558, \mathrm{D}-4853, \mathrm{D}-4854$ \\
\hline \multicolumn{2}{|l|}{ F. oxysporum f. sp. niveum Fon- 8822} & F. pseudoanthophilum 10755 \\
\hline F. oxysporum f. sp. phaseoli Fop-DR85 & Unknown & F. pseudocircinatum 10761 \\
\hline \multicolumn{2}{|l|}{ F. oxysporum f. sp. pisi } & F.pseudograminearum 11435 \\
\hline \multirow[t]{2}{*}{ Fo-506, -526} & Italy & F. trincictum 11566 \\
\hline & & F. verticillioides 11556, A-149, A-999 \\
\hline
\end{tabular}

${ }^{a}$ Race of $F$. oxysporum f. sp. ciceris was determined by pathogenicity tests on differential chickpea lines before PCR assays $(18,23,26)$.

${ }^{\mathrm{b}}$ Isolates of $F$. oxysporum of formae speciales lycopersici, melonis, niveum, and phaseoli were from the fungal culture collection of Departamento de Protección de Cultivos, Instituto de Agricultura Sostenible (IAS-CSIC), Córdoba, Spain. Isolate of $F$. oxysporum f. sp. lycopersici Fol-325-3 was provided by D. Fravel, United States Department of Agriculture-Agricultural Research Service (USDA-ARS) Vegetable Development Laboratory, Beltsville, MD. Isolates of $F$. oxysporum f. sp. pisi were provided by W. Boge, USDA-ARS Pacific West Area, Prosser, WA. Isolates from Algeria, Italy, Morocco, Spain, and the United States (California) were obtained from the fungal culture collection of Departamento de Protección de Cultivos, IAS-CSIC, Córdoba, Spain. Foc isolates from India were provided by M. P. Haware, ICRISAT, Hyderabad, India; isolates from Tunisia were provided by M. H. Halila, Institute Nacionale de la Recherche Agronomique, Ariana, Tunisia; isolates from Israel were provided by J. Katan, Department of Plant Pathology and Microbiology, The Hebrew University of Jerusalem, Israel; isolates from Lebanon, Syria, and Turkey were provided by C. Akem, ICARDA, Aleppo, Syria. F. oxysporum isolates listed as nonpathogenic are not pathogenic to chickpea. Unknown $=$ geographic origin not known.

${ }^{\mathrm{c}}$ Isolates of other Fusarium spp. were obtained from J. F. Leslie, Department of Plant Pathology, Kansas State University, Manhattan, Kansas. Geographic origins of these latter isolates were not provided. 
Maths, Sint-Martens-Latem, Belgium) (Table 3). An in silico test of primer specificity was conducted by running the primer sequences against the nonredundant GenBank data set with parameters set for the identification of short, nearly exact matches.

Reaction conditions such as annealing temperature, $\mathrm{MgCl}_{2}$, and primer concentrations were adjusted experimentally to optimize the amplification with each primer pair. All reactions were repeated at least twice and always included positive ( $F$. oxysporum f. sp. ciceris DNA, isolate Foc-9605) and negative controls (i.e., DNA from other Fusarium spp., nonpathogenic F. oxysporum, or other formae speciales of $F$. oxysporum and no template DNA). Amplification products were separated by electrophoresis in $2 \%$ agarose gels in $1 \times$ TAE buffer for 60 to $120 \mathrm{~min}$ at $80 \mathrm{~V}$, stained with ethidium bromide, and visualized under UV light. The generuler DNA ladder mix (Fermentas, St Leon-Rot, Germany) was used for electrophoresis.

Optimization, reproducibility, and sensitivity of the newly developed q-PCR protocol. Reaction conditions (i.e., volume of reaction, annealing temperature, primer concentration, temperature to measure the fluorescence signal of the amplicon, etc.) were adjusted experimentally to optimize the q-PCR protocol using both primer pairs and DNA standard curves W/Foc-9605 and CS/Foc-9605. All q-PCR amplifications were performed using the iQ SYBR Green Supermix, iQ 96-thin well PCR plates and Optical sealing tape (Bio-Rad, Madrid, Spain), and the iCycler IQ apparatus (Bio-Rad). After the final amplification cycle, a melting curve temperature profile was obtained by heating to $95^{\circ} \mathrm{C}$, cooling to $55^{\circ} \mathrm{C}$, and slowly heating to $95^{\circ} \mathrm{C}$ at $0.5^{\circ} \mathrm{C}$ every $10 \mathrm{~s}$ with continuous measurement of fluorescence at $520 \mathrm{~nm}$. All reactions were analyzed by gel electrophoresis to confirm that only one PCR product was amplified from samples containing genomic DNA of F. oxysporum f. sp. ciceris isolates and no amplification product was obtained from negative controls.

The potential influence of host DNA and/or its source (plant tissue: root versus stem) as well as of DNA extracted from soil on the efficiency of q-PCR amplifications was also assessed in different experiments. For that aim, only primer pair FOCP1 was used because in previous assays it proved to be more efficient and provided more reproducible results compared to that obtained with primer set FOCP2. For those experiments, comparisons of DNA backgrounds were done in the same 96-well PCR plate. Quantitative PCR amplifications of each series of DNA standard curves included three replications per treatment and plate. All experiments were repeated twice independently (different PCR plates, operators and DNA standard curves) and always included a common DNA standard curve to compare variability between as well as within experiments. Finally, the sensitivity of the q-PCR protocol was determined using two series of three DNA standard curves (W/Foc-9605, CR/Foc-9605, and SM/Foc-9605) and compared with the simple PCR protocol using primer set FOCP1.

Evaluation of chickpea resistance and virulence of $F$. oxysporum f. sp. ciceris isolates using the q-PCR protocol. An experiment was set up to determine the use of the newly developed q-PCR protocol for evaluating the level of resistance in chickpea cultivars to races of $F$. oxysporum f. sp. ciceris. Isolates Foc-USA W6-1 (race 5; highly virulent) and Foc-7802 (race 0; mildly virulent) were used $(30,39)$. Inocula of isolates for the experiment were increased in a cornmeal-sand mixture (CMS) as previously described (56). Inoculum density in that mixture (number of colony forming units (cfu) per gram of infested CMS) was determined by dilution plating on V8 juice-oxgall-pentachloronitrobenzene agar (VOPA), a Fusarium-semiselective medium (6). Then, the infested CMS was thoroughly mixed with an autoclaved $\left(121^{\circ} \mathrm{C}\right.$, for $75 \mathrm{~min}$, twice) soil mixture (clay loam $/ \mathrm{sand} /$ peat, $1: 1: 1, \mathrm{vol} / \mathrm{vol} / \mathrm{vol}$ ) in the appropriate proportion to obtain an inoculum density of $10^{5} \mathrm{cfu}$ per gram of soil.

Chickpea cvs. P-2245 and JG-62 were used in this experiment. These cultivars show well-characterized differential resistance reactions to isolates Foc-USA W6-1 and Foc-7802 (Table 2) (18). Germinated seeds, selected for uniformity (length of radicle $=1$ to $2 \mathrm{~cm}$ ), were sown in $15-\mathrm{cm}$-diameter clay pots (one plant per

TABLE 2. Differential chickpea cultivars and lines and Fusarium wilt reactions to the different Fusarium oxysporum f. sp. ciceris races

\begin{tabular}{|c|c|c|c|c|c|c|c|c|}
\hline \multirow{2}{*}{$\begin{array}{l}\text { Chickpea } \\
\text { cultivar/line }\end{array}$} & \multicolumn{8}{|c|}{ F. oxysporum f. sp. ciceris race and wilt reaction ${ }^{\mathrm{a}}$} \\
\hline & 0 & $1 \mathrm{~A}$ & $1 \mathrm{~B} / \mathrm{C}$ & 2 & 3 & 4 & 5 & 6 \\
\hline PV-1 & $\mathrm{S}$ & M & $\mathrm{S}$ & $\mathrm{R}$ & $\mathrm{R}$ & $\mathrm{R}$ & $\mathrm{R}$ & $\mathrm{R} / \mathrm{M}^{\mathrm{b}}$ \\
\hline JG-62 & $\mathrm{R}$ & $\mathrm{S}$ & S/M & $\mathrm{S}$ & $\mathrm{S}$ & $\mathrm{S}$ & $\mathrm{S}$ & S \\
\hline CPS-1 & $\mathrm{R}$ & $\mathrm{R}$ & $\mathrm{R}$ & $\mathrm{S}$ & $\mathrm{M}$ & M & $\mathrm{M}$ & $\mathrm{R}$ \\
\hline BG-212 & $\mathrm{R}$ & $\mathrm{R}$ & $\mathrm{R}$ & $\mathrm{S}$ & M & M & $\mathrm{R}$ & $\mathrm{R}$ \\
\hline WR-315 & $\mathrm{R}$ & $\mathrm{R}$ & $\mathrm{R}$ & $\mathrm{R}$ & $\mathrm{S}$ & $\mathrm{R}$ & $\mathrm{R}$ & $\mathrm{R}$ \\
\hline UC-15 & $\mathrm{R}$ & $\mathrm{R}$ & $\mathrm{R}$ & $-^{\mathrm{c}}$ & - & - & $\mathrm{R}$ & $\mathrm{R}$ \\
\hline ICCV-2 & $\mathrm{R}$ & $\mathrm{R}$ & $\mathrm{R}$ & $\mathrm{S}$ & $\mathrm{S}$ & $\mathrm{S}$ & $\mathrm{S}$ & M \\
\hline ICC-14216K & $\mathrm{R}$ & $\mathrm{R}$ & $\mathrm{R}$ & $\mathrm{R}$ & - & - & $\mathrm{R}$ & $\mathrm{R}$ \\
\hline CA-334.20.4 & $\mathrm{R}$ & $\mathrm{S}$ & $\mathrm{R}$ & - & - & - & $\mathrm{R}$ & $\mathrm{R}$ \\
\hline PV-60 & $\mathrm{R} / \mathrm{M}$ & $\mathrm{S}$ & $\mathrm{S}$ & - & - & - & $\mathrm{S}$ & $\mathrm{S}$ \\
\hline PV-61 & $\mathrm{R} / \mathrm{M}$ & $\mathrm{S}$ & $\mathrm{S}$ & - & - & - & $\mathrm{S} / \mathrm{M}$ & $\mathrm{S}$ \\
\hline P-2245 & $\mathrm{S}$ & $\mathrm{S}$ & $\mathrm{S}$ & $\mathrm{S}$ & $\mathrm{S}$ & $\mathrm{S}$ & S & $\mathrm{S}$ \\
\hline
\end{tabular}

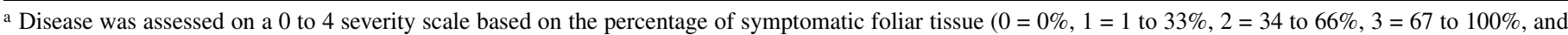
$4=$ dead plant) at the end of the experiment (33). Average disease severity ratings $<1$ and $>3$ at the end of the experiments were considered resistant (R) and susceptible (S), respectively (30,33). Intermediate severity ratings $(\geq 1$ and $\leq 3)$ were considered moderately susceptible (M) reactions $(21,30,33)$.

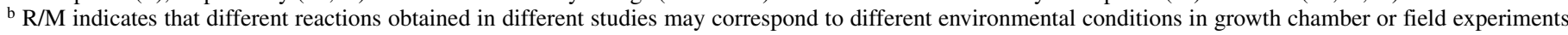
(33) or use of different accessions of chickpea cultivars and lines $(52,54)$.

c - indicates unknown reaction.

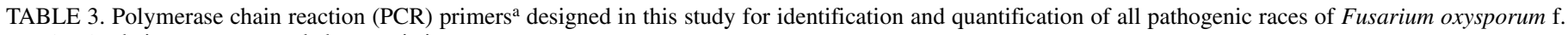
sp. ciceris, their sequences, and characteristics

\begin{tabular}{|c|c|c|c|c|c|}
\hline Primer set & Primer name & Sense & Sequence $\left(5^{\prime}-3^{\prime}\right)$ & Melting temperature $\left({ }^{\circ} \mathrm{C}\right)$ & Amplicon size (bp) \\
\hline \multirow[t]{2}{*}{ FOCP1 } & IV-SP & Forward & TACGGTACCAGATCATGGCGT & 71 & 160 \\
\hline & IV-ASP & Reverse & CGCTTTCGATCGTGGCTATG & 70 & \\
\hline \multirow[t]{2}{*}{ FOCP2 } & P3-SP & Forward & CATGGTTTCGTTAGGCCAGT & 68 & 158 \\
\hline & P3-ASP & Reverse & CGCAGTCTTCGTCGTCATTA & 68 & \\
\hline
\end{tabular}

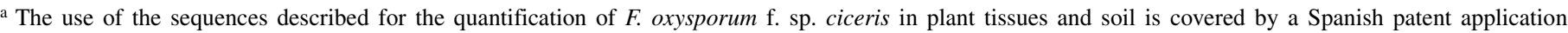
P201031615 owned by Spanish National Research Council (CSIC) and University of Córdoba. 
pot) filled with the infested soil mixture and incubated inside a walk-in growth chamber adjusted to $25 \pm 1{ }^{\circ} \mathrm{C}$ and a 14-h photoperiod of fluorescent light at $360 \mu \mathrm{E} \mathrm{m} \mathrm{m}^{-2} \mathrm{~s}^{-1}$ for 45 days. There were 14 chickpea plants per cultivar-isolate combination. For each combination, six plants were sampled for DNA extraction 15 days after sowing. The remaining eight plants were used for assessing disease development up to 45 days after sowing, a time period commonly used in Fusarium wilt resistance screening assays (33). Plants were removed from pots, gently washed under running tap water, surface-disinfested in $2 \% \mathrm{NaOCl}$ for $1.5 \mathrm{~min}$, and dried between sheets of filter paper. From each of sampled plants, separated roots and stem were frozen in liquid nitrogen and stored at $-80^{\circ} \mathrm{C}$. DNA was extracted from $100 \mathrm{mg}$ of frozen main stem or main root tissues as described above.

Incidence, $I$ ( 0 to 1 scale), and severity of foliar symptoms, $S$, (rated on a 0 to 4 scale) were assessed on individual plants at 2- to 3 -day intervals (30). Average scores of final severity $<1$ and $>3$ were considered resistant and susceptible reactions, respectively; and scores in between those values $(\geq 1$ and $\leq 3)$ were considered moderately susceptible reactions $(30,33)$.

The use of the q-PCR protocol for quantifying $F$. oxysporum $\mathrm{f}$. sp. ciceris DNA in field-grown chickpeas was also validated. To that aim, DNA was extracted from roots of chickpea cvs. PV-1, PV-60, BG-212, P-2245, ICCV-2, UC-15, JG-62, CA334.20.4, ICC14216, PV-61, WR-315, and CPS-1 that grew in a field plot located at 'Campus de Rabanales' Experiment Station, University of Córdoba, Spain. The soil of this field plot (Vertisol, Haploxerets soil; $50 \%$ clay, $33 \%$ silt, $17 \%$ sand; $\mathrm{pH} 8.6,1.4 \%$ organic matter) is infested with a mixture of different populations of $F$. oxysporum including races 0,5 , and 6 of $F$. oxysporum f. sp. ciceris (28; S. Garcés-Romay, R. M. Jiménez-Díaz and B. B. Landa, unpublished data). There were three blocks with two-row plots for each cultivar; the rows being $40 \mathrm{~m}$ long and $25 \mathrm{~cm}$ apart. Seeds were hand-sown at $5 \mathrm{~cm}$ depth. Weeds in the plot were removed by hand, and insecticides and fertilizers were applied according to farmer's practices. At the initial-flowering crop stage (approximately 35 days after sowing), three plants free from $\mathrm{Fu}-$ sarium wilt symptoms were arbitrarily selected within each row, carefully uprooted, and the excess soil on roots removed by gentle shaking. Then, the entire root system of the six plants from each replicated block were pooled in a plastic bag, transferred to the laboratory, and stored at $4^{\circ} \mathrm{C}$ until use. DNA was extracted from $50 \mathrm{mg}$ of lyophilized chickpea roots as described above. In this experiment, lyophilized roots instead of fresh-frozen ones were used for increased uniformity of the processed samples of infected roots. In previous assays, no significant differences $(P \geq$ $0.05)$ were found in q-PCR amplifications when the DNA was extracted from fresh or lyophilized root tissues (data not shown). Following the sampling of symptomless plants, the disease reaction was assessed on the 12 selected chickpea cultivars in the plot by recording the incidence of Fusarium wilt-affected and dead plants at 10- to 15-day intervals during the entire growing season.

The amount of $F$. oxysporum f. sp. ciceris DNA in the root and stem samples was estimated using the optimized q-PCR conditions and the CR/Foc-9605 standard curve (serial dilutions of Foc-9605 DNA in a fixed background of chickpea root DNA of $10 \mathrm{ng} / \mu \mathrm{l})$ and six replicated plants. The PCR assay was repeated twice for each sample.

Quantification of $F$. oxysporum $\mathbf{f}$. sp. ciceris in soil using the q-PCR protocol. For artificial inoculation, inocula of $F$. oxysporum f. sp. ciceris isolates Foc-7802 and Foc-USA W6-1 were increased in $100 \mathrm{ml}$ of potato dextrose broth (Difco Laboratories) in flasks as previously described (32). The liquid cultures were filtered through eight layers of sterile cheesecloth, and conidia were harvested by centrifugation $(10,000 \times g$ for $10 \mathrm{~min}$ ) and washed twice with sterile distilled water to remove traces of nutrients. Inoculum concentration (mainly microconidia) in the suspension was estimated using a hemacytometer and adjusted to $2 \times 10^{4} \mathrm{cfu} / \mathrm{ml}$ using SUW. A natural soil (Entisol, Xerofluvents; $27 \%$ clay, $9.3 \%$ silt and $63.8 \%$ sand; $\mathrm{pH} 7.4,1.9 \%$ organic matter) that had been previously assayed for the absence of $F$. oxysporum f. sp. ciceris was pasteurized at $74^{\circ} \mathrm{C}$ for $30 \mathrm{~min}$, air dried at room temperature $\left(24\right.$ to $\left.28^{\circ} \mathrm{C}\right)$ for 1 week, and sieved through mesh $(1 \times 1 \mathrm{~cm})$. Then, $10 \mathrm{ml}$ of the microconidia suspension $\left(2 \times 10^{4} \mathrm{cfu} / \mathrm{ml}\right)$ of each isolate was thoroughly mixed with $100 \mathrm{~g}$ of soil in a plastic bag to get approximately $2 \times 10^{3}$ $\mathrm{cfu} / \mathrm{g}$. The infested soil was then air dried as before and stored at $4{ }^{\circ} \mathrm{C}$ for 5 months before use. Additionally, a sample from the naturally infested soil from the field plot located at 'Campus de Rabanales' was used. Soil was air dried and sieved as described above before DNA extraction.

The number of $F$. oxysporum f. sp. ciceris propagules in the artificially and naturally infested soil samples was determined, at the same time as the DNA extraction, by dilution plating using six replicates of $1 \mathrm{~g}$ each per soil type as previously described (32). Serial dilutions of the soil suspensions were plated onto Fusarium-semiselective VOPA medium and incubated at $25 \pm 1{ }^{\circ} \mathrm{C}$ with a 12-h photoperiod of fluorescent and near-UV light at $36 \mu \mathrm{E}$ $\mathrm{m}^{-2} \mathrm{~s}^{-1}$ for 5 days. There were two replicated plates per dilution and soil sample. After 5 days of incubation, the number of cfu of Fusarium spp. (field soil) and F. oxysporum f. sp. ciceris (artificially infested soil) were counted. Then, approximately $10 \%$ of colonies derived from the naturally infested soil samples resembling $F$. oxysporum by microscopic observation of fungal structures were arbitrarily selected from the dilution plates and transferred to PDA. DNA from putative $F$. oxysporum isolates was obtained as described above and assayed by PCR using the $F$. oxysporum f. sp. ciceris-specific primer pair FOCP1.

The amount of $F$. oxysporum f. sp. ciceris DNA in the soil samples was estimated using the optimized q-PCR conditions and the SM/Foc-9605 standard curve (serial dilutions of Foc-9605 DNA in a fixed background of soil DNA of $10 \mathrm{ng} / \mu \mathrm{l}$ ). There were six replicated samples per soil type and two PCR assays per sample.

Data analyses. The cycle threshold $\left(\mathrm{C}_{\mathrm{T}}\right)$ values for each reaction were defined as the $\mathrm{PCR}$ cycle number at which the fluorescence signal exceeded background using the default estimation criteria in the iCycler IQ software version 3.0a (Bio$\mathrm{Rad}$ ). Then, to compare and establish relationships among the different DNA standard curves generated from different treatments, the threshold position was manually defined and fixed at the same position for all treatments and experiments (57). The amplification efficiency (AE) was calculated from the slopes of the standard curves using the equation $\mathrm{AE}=10^{(1 / \mathrm{slope})}-1(1,16)$.

Linear regression analyses of the natural logarithm of known concentrations of the target DNA versus the $C_{T}$ values were performed for each DNA standard curve by using the GLM procedure of SAS (Statistical Analysis System, version 9.1; SAS Institute, Cary, NC). Standard regression lines from each plate chosen as reference curves were used for transforming the experimental $\mathrm{C}_{\mathrm{T}}$ values into amounts of pathogen DNA (ng). All standard regression lines obtained for the different plant DNA backgrounds were statistically compared for homogeneity $(P \geq$ 0.05 ) of variance (Bartlett's test) and for equality of slopes and intercepts using a $F$ test at $P<0.05$. Data for $F$. oxysporum f. sp. ciceris populations were converted to $\log \mathrm{cfu} / \mathrm{g}$ of fresh weight of root to satisfy the assumptions of the parametric statistical test used. Differences in $F$. oxysporum f. sp. ciceris concentration between chickpea cultivars and pathogen races were determined by standard analysis of variance, and treatment means were compared according to Fisher's protected least significant difference test at $P<0.05$ using the GLM procedure of SAS. Regression analyses were performed to determine the relationship between the inoculum concentration of $F$. oxysporum $\mathrm{f}$. sp. ciceris in roots of the different chickpea cultivars and final disease incidence using the GLM procedure of SAS. 


\section{RESULTS}

Design of a new $F$. oxysporum f. sp. ciceris-specific PCR protocol. Primer sets FOCP1 and FOCP2 were adequate for the specific identification of $F$. oxysporum $\mathrm{f}$. sp. ciceris. They were designed from a SCAR sequence specific for this forma specialis (AF492451) (22). Primers in each set were first verified that they did not show homology with sequences deposited in GenBank. Thereafter, several parameters of the PCR protocol were evaluated to optimize amplification results. Primer designation and sequences, and PCR products with optimized amplification conditions are presented in Table 3 . The optimized reaction mix was similar for both primer pairs (final volume $20 \mu \mathrm{l}$ ): $2.0 \mu \mathrm{l}$ of $10 \times$ reaction buffer $\left(160 \mathrm{mM}\left(\mathrm{NH}_{4}\right)_{2} \mathrm{SO}_{4}, 670 \mathrm{mM}\right.$ Tris- $\mathrm{HCl}[\mathrm{pH} 8.8$ at $25^{\circ} \mathrm{C}$ ], $0.1 \%$ stabilizer; [Bioline, London, UK]), $0.35 \mu \mathrm{M}$ of each primer, $200 \mu \mathrm{M}$ of each dNTP, 1 unit of BioTaq DNA polymerase
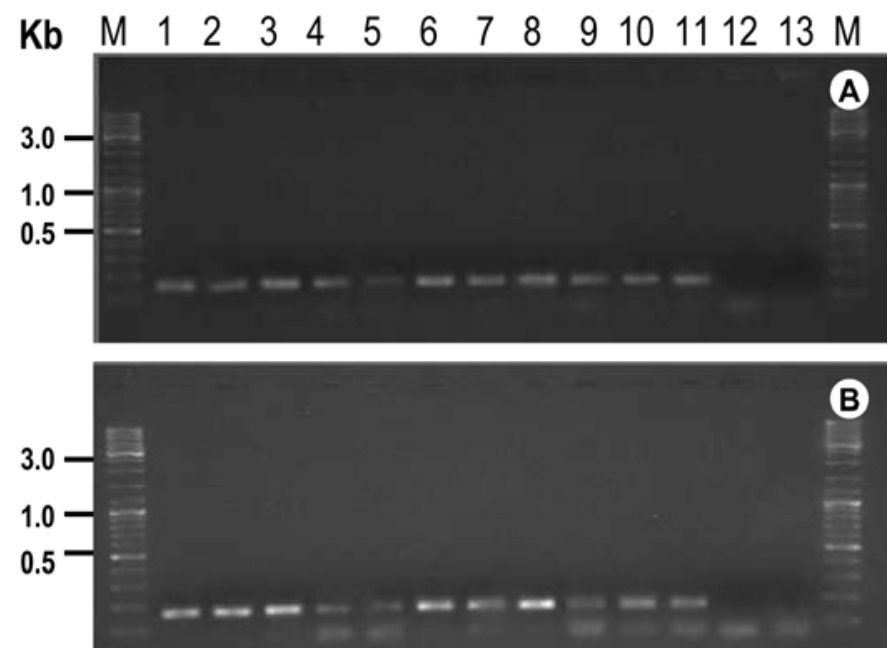

Fig. 1. Agarose gels showing amplification products from polymerase chain reaction using A, FOCP1 or $\mathbf{B}$, FOCP2 primer sets and genomic DNA from isolates of Fusarium oxysporum f. sp. ciceris. M, gene-ruler DNA ladder mix (Fermentas, St Leon-Rot, Germany). Lanes 1 to 11, F. oxysporum f. sp. ciceris isolates Foc-cc62R and Foc-9032 (Race 0), Foc-cc-22D (Race 1B/C), Foc9166 and Foc-9027 PV1 (Race 1A), Foc-8605 (Race 2), Foc-8606 (Race 3), Foc-8607 (Race 4), Foc-8508 and Foc-USA 1-1 JG-62 (Race 5), and Foc-8924 (Race 6); lane 12, chickpea DNA; and lane 13, negative control (water), respectively.
(Bioline), $1.5 \mathrm{mM} \mathrm{MgCl}$, and $1 \mu \mathrm{l}$ of template DNA (20 to $40 \mathrm{ng}$ of DNA). Amplifications were performed in a C1000 (Bio-Rad) thermocycler. The cycling program included an initial denaturation step of $1 \mathrm{~min}$ at $94^{\circ} \mathrm{C}$, followed by 25 cycles of $30 \mathrm{~s}$ denaturation at $94^{\circ} \mathrm{C}, 30 \mathrm{~s}$ annealing at $55^{\circ} \mathrm{C}$ and $30 \mathrm{~s}$ extension at $72^{\circ} \mathrm{C}$. The final cycle consisted of $5 \mathrm{~min}$ at $72^{\circ} \mathrm{C}$ followed by a $4^{\circ} \mathrm{C}$ soak.

Simple PCR assays using primer sets FOCP1 and FOCP2 and genomic DNA of 42 F. oxysporum f. sp. ciceris isolates, representing the eight races and from a wide geographic range, amplified only a product of 160 and $158 \mathrm{bp}$, respectively (Fig. 1; Table 1). Occasionally, some primer dimmers were observed for primer set FOCP2 (Fig. 1). None of those specific products were amplified when DNA of isolates of nonpathogenic $F$. oxysporum (six), other formae speciales of $F$. oxysporum (eight), and other Fusarium spp. (59) were used as template for specific PCR assays with primers sets FOCP1 and FOCP2 (Fig. 2; only results for primer set FOCP1 are shown).

Optimization of the q-PCR protocol specific for $F$. oxysporum f. sp. ciceris. A step-by-step, fine-tuning process was done for each of primer sets FOCP1 and FOCP2, which involved the following PCR parameters: primer concentration, annealing temperature, and final volume of PCR reactions. This was performed using DNA standard curves W/Foc-9605 and CS/Foc9605. Reducing the standard reaction volume from 50 to $20 \mu \mathrm{l}$ had no effect on the accuracy of the assay (data not shown). Consequently, a final volume of $20 \mu \mathrm{l}$ was chosen to minimize the cost per q-PCR assay.

The optimized PCR mixture consisted of (final volume of $20 \mu \mathrm{l}$ ) $1 \mu \mathrm{l}$ of DNA sample, $1 \times$ iQ SYBR Green Supermix (Bio-Rad), and $0.3 \mu \mathrm{M}$ of each primer. The thermal cycling conditions consisted of an initial denaturation at $95^{\circ} \mathrm{C}$ for $1 \mathrm{~min}$ followed by 40 cycles of $30 \mathrm{~s}$ at $95^{\circ} \mathrm{C}, 30 \mathrm{~s}$ at $55^{\circ} \mathrm{C}$, and $30 \mathrm{~s}$ at $72^{\circ} \mathrm{C}$. Fluorescence of the target amplicon was detected at $72^{\circ} \mathrm{C}$. Occasionally, we observed that weak peaks occurred between 72 and $75^{\circ} \mathrm{C}$ in the melting curve, especially for primer set FOCP2. This was due to primer dimers since these nonspecific amplifications were not detected by electrophoresis in $1.2 \%$ (wt/vol) agarose gel (data not shown). No fluorescence signal occurred for negative controls using water or any of DNAs extracted from chickpea tissues. A threshold position of 200 relative fluorescence units was fixed for all experiments to determine $C_{T}$ values.

Although use of each of primer sets yielded highly reproducible amplifications, standard regression lines obtained for primer set

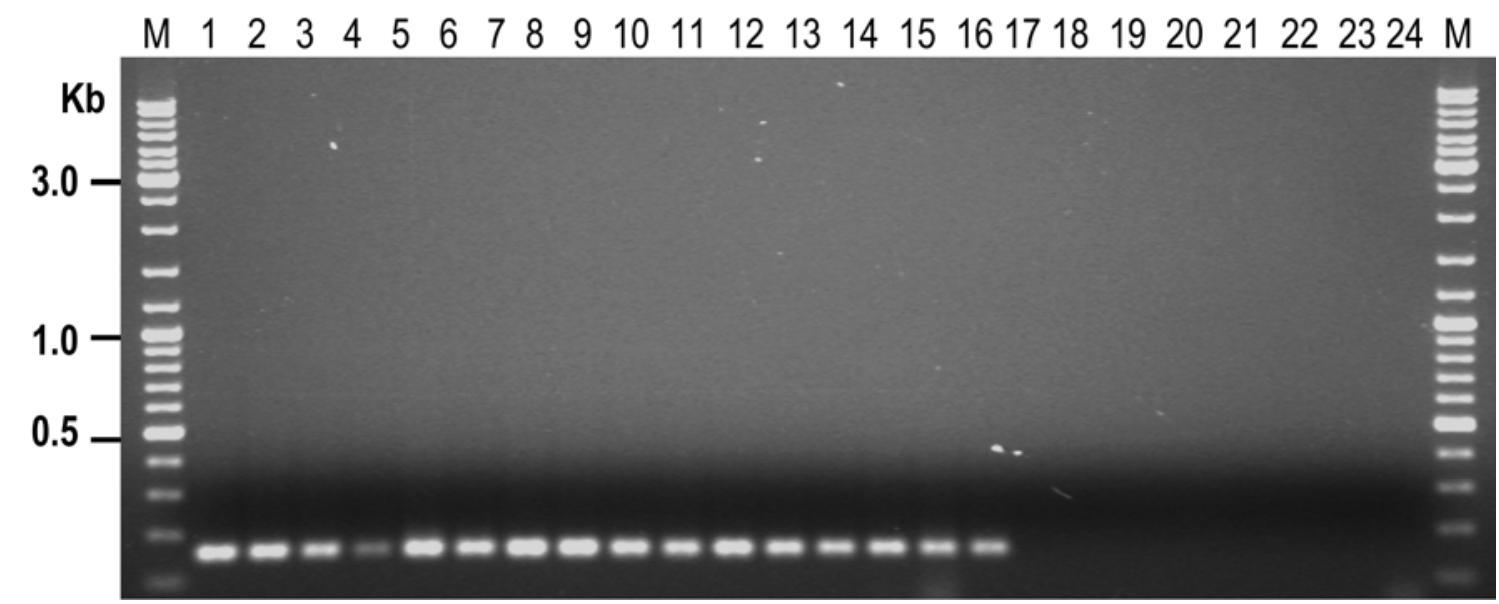

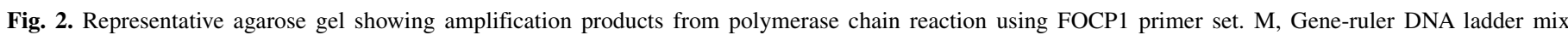

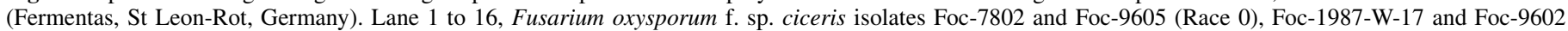

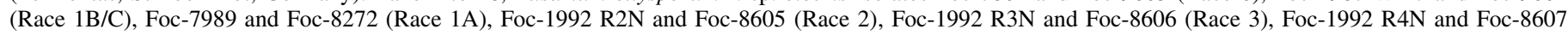

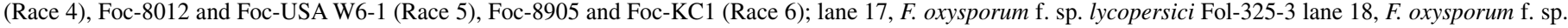

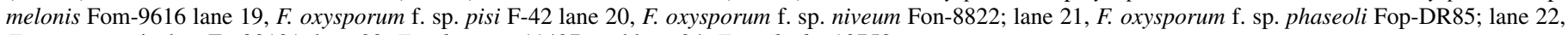
F. oxysporum isolate Fo-90101; lane 23, F. culmorum 11427; and lane 24, F. nisikadoi 10758. 
FOCP1 indicated slightly better reproducibility, better efficiency and higher values of the coefficient of determination (amplification efficiency $[\mathrm{AE}]=93.9$ to $102.6 \% ; R^{2}=0.991$ to 0.999$)$ compared with those of primer set FOCP2 ( $\mathrm{AE}=81.7$ to $104.9 \%$; $R^{2}=0.989$ to 0.998). Consequently, primer set FOCP1 was chosen for subsequent experiments.

After optimizing the q-PCR protocol, standard regression lines were generated for each of DNA standard curves using a range of DNA from $10 \mathrm{ng}$ to $0.1 \mathrm{pg}$. Use of the q-PCR protocol with independently built DNA standard curves or by different operators did not influence reproducibility and consistency of results (data not shown). A high reproducibility of amplifications with a high efficiency was achieved over 5 orders of magnitude of DNA concentration, which exhibited a linear dynamic range of amplification. $F$. oxysporum f. sp. ciceris DNA was not accurately quantified at a concentration of $0.1 \mathrm{pg}$ if DNA was diluted in either water or in DNA extracted from chickpea stem or root tissues or soil; i.e., $\mathrm{C}_{\mathrm{T}}$ value of $34.5 \pm 2$ or no amplification (Table 4). Consequently, the detection limit of the q-PCR assay was fixed at F. oxysporum DNA concentration of $0.1 \mathrm{pg}$ or a $\mathrm{C}_{\mathrm{T}}$ of 35 cycles.

One-way analysis of variance of $\mathrm{C}_{\mathrm{T}}$ values derived from W/Foc-9605, CR/Foc-9605, CS/Foc-9605, and SM/Foc-9605 DNA standard curves indicated homogeneity of variances $(P \geq$ 0.05 ). The source of the background DNA (water versus chickpea roots or chickpea stems or soil) did not influence $(P \geq 0.05)$ results of q-PCR assays (Fig. 3). Statistical comparisons of the standard regression lines of the four DNA standard curves indicated lack of significant differences among intercepts $(P=0.0970)$ or slopes $(P=0.2556)$ (Table 4$)$. Since use of DNA backgrounds from different host plant tissues or soil did not influence reproducibility and efficiency of assays, we selected the CR/Foc-9605 DNA standard curve to estimate the amount of $F$. oxysporum $\mathrm{f}$. sp. ciceris DNA in naturally infected plant tissues, and the SM/Foc-

TABLE 4. Standard regression equations from standard curves ${ }^{\mathrm{a}}$ of Fusarium oxysporum f. sp. ciceris DNA diluted in different DNA backgrounds, and sensitivity of F. oxysporum f. sp. ciceris-specific primers used in conventional or real-time quantitative polymerase chain reaction (PCR) assays

\begin{tabular}{|c|c|c|c|c|c|c|}
\hline \multirow[b]{2}{*}{ Background DNA } & \multicolumn{4}{|c|}{ Regression parameters ${ }^{\mathrm{b}}$} & \multicolumn{2}{|c|}{ Sensitivity of PCR } \\
\hline & Intercept & Slope & $\mathrm{AE}(\%)^{\mathrm{c}}$ & $R^{2}$ & Conventional (ng) & Quantitative $\left(\mathrm{ng} ; \mathrm{C}_{\mathrm{T}}\right)$ \\
\hline Water & 21.75 & -3.463 & 94.43 & 0.993 & 1 & $0.001 ; 32.44 \pm 0.64$ \\
\hline Stem & 22.40 & -3.261 & 102.60 & 0.995 & 1 & $0.001 ; 31.60 \pm 0.35$ \\
\hline Soil & 22.01 & -3.477 & 93.91 & 0.996 & 1 & $0.001 ; 31.80 \pm 0.40$ \\
\hline$P$ value & 0.0970 & 0.2556 & & & & \\
\hline
\end{tabular}

a Standard curves were obtained by five-point 10-fold serial dilution of $F$. oxysporum f. sp. ciceris DNA Foc-9605 (10 ng/ $\mu$ l) to obtain from $10 \mathrm{ng}$ to $0.1 \mathrm{pg}$ of DNA per PCR diluted in sterile distilled water or in DNA extracted from chickpea roots or stems (10 ng of background DNA) or from an artificial soil mixture (10 ng of background DNA) to investigate any possible influence of host or soil DNA on sensitivity of PCR reactions. Numbers shown in the quantitative PCR assays correspond to an average of eight $\mathrm{C}_{\mathrm{T}}$ values \pm standard deviation from two independent standard curves, each performed by two independent operators and two replications within each plate.

${ }^{\mathrm{b}}$ Parameters from regression equations were statistically compared for homogeneity $(P \geq 0.05)$ of variance (Bartlett's test) and for equality of slopes and intercepts using a $F$ test at $P<0.05$.

${ }^{c}$ The amplification efficiency (AE) was calculated from the slopes of the standard curves using the equation $\mathrm{AE}=10^{(1 / \mathrm{slope})}-1(1,16)$.

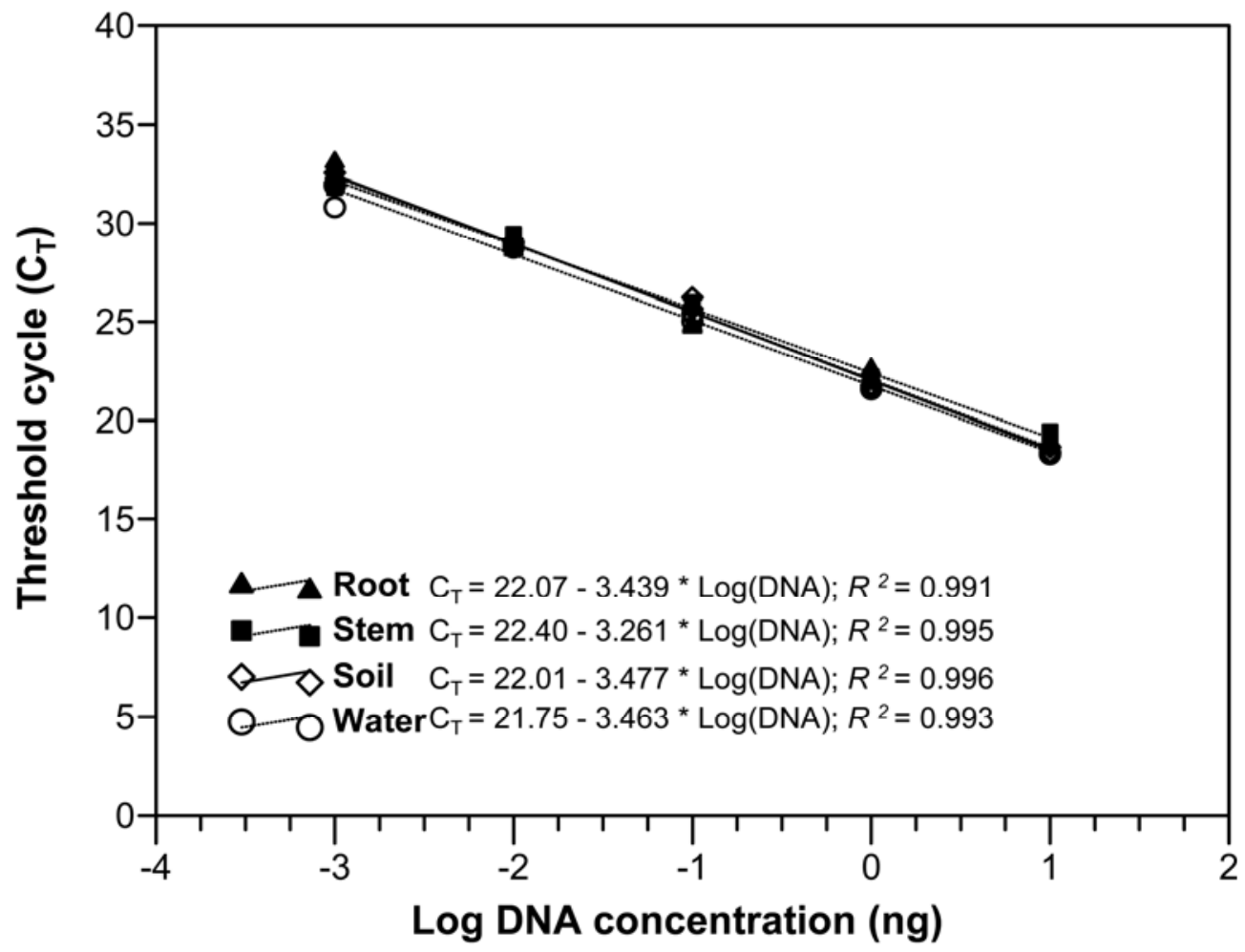

Fig. 3. Standard regression lines of a five-point 10-fold serial dilution of Fusarium oxysporum f. sp. ciceris (Foc-9605) DNA (10 ng/ $\mu$ ) diluted in sterile, ultrapure water (water series) or in DNA (10 ng) extracted from chickpea stems or roots, or from soil (10 ng). Threshold cycles $\left(\mathrm{C}_{\mathrm{T}}\right)$ were plotted against the log of genomic DNA standard curves of known concentrations. 
9605 DNA standard curve to estimate that in naturally or artificially infested soil.

Use of the developed q-PCR protocol for resistance screening and studies on $F$. oxysporum f. sp. ciceris population biology. Neither resistant 'JG-62' nor susceptible 'P-2245' chickpea plants inoculated with mildly virulent $F$. oxysporum f. sp. ciceris race 0 showed symptoms at the time of sampling, 15 days after sowing in infested soil. On the contrary, at this same time, disease incidence in 'JG-62' and 'P-2245' plants inoculated with the highly virulent race 5 was 33.3 and $54.3 \%$, respectively. Nevertheless, the mean severity $(S)$ of symptoms was very low $(S<0.5)$ (Fig. 4C). At the end of the experiment, 45 days after sowing, all plants in compatible combinations (i.e., 'P-2245'/race 0 , 'P-2245'/race 5 and 'JG-62'/race 5) were dead (i.e., $S=4$ ).

Use of the q-PCR protocol allowed detection of $F$. oxysporum $\mathrm{f}$. sp. ciceris in all root samples of all plants irrespective of the cultivar/race combination at 15 days after sowing in infested soil. However, the amounts of pathogen DNA assessed in root tissues of plants for the most compatible combinations highly susceptible cultivar/highly virulent race (i.e., 'P-2245'/race 5, 'JG-62'/race 5) were significantly $(P=0.0002)$ higher compared with that estimated in the incompatible resistant combination ('JG-62'/race 0 ), as well as the lesser compatible one ('P-2245'/race 0) (Fig. 4A). No significant differences $(P=0.2017)$ were detected for pathogen DNA concentration in roots of the two chickpea cultivars for both races at 15 days after sowing in infested soil (Fig. 4A).

Assays using DNA extracted from chickpea stems 15 days after sowing in infested soil were negative in all samples from the incompatible combination ('JG-62'/race 0), but succeeded in $33.3 \%$ of stem samples from 'P-2245' plants inoculated with this same race 0 (Fig. 4B). However, significantly $(P=0.0083)$ higher amounts of the pathogen were detected in a higher percentage of stem samples from the most compatible combinations (i.e., 'P2245 '/race 5 and 'JG-62'/race 5); with the amount of race 5 detected in the stem of 'JG-62' being significantly smaller $(P=$ 0.0006) than that in 'P-2245' (Fig. 4B).

Use of the q-PCR protocol allowed detection of $F$. oxysporum $\mathrm{f}$. sp. ciceris DNA in $100 \%$ of root samples from the three chickpea cultivars ('PV-61', 'P-2245', and 'PV-60') sown in the naturally infested field plot that are susceptible to races present in this soil $(0,5$, and 6$)$. Similarly, there were $100 \%$ positive detection in root samples of 'PV-1' and 'JG-62' that are, respectively, susceptible to moderately susceptible to races 0 and 6 , and susceptible to races 5 and 6 . Also, there was $83.3 \%$ of positive detection in root samples of 'ICCV-2', which is resistant to race 0 but susceptible to races 5 and 6 , and only $41.7 \%$ detection in root samples of 'CPS-1', which is moderately susceptible to race 5 but resistant to races 0 and 6 (Fig. 5). The relative amount of $F$. oxysporum f. sp. ciceris DNA in root samples of chickpea cultivars susceptible to races 0,5 or 6 differed significantly $(P<0.0001)$ among cultivars, ranging from $0.21 \%$ in cv. ICCV-2 to $10.21 \%$ in cv. P-2245 (Fig. $5)$. The final disease incidence of dead plants in the susceptible cultivars by 85 days after sowing was significantly and positively correlated $(r=0.8722 ; P=0.0235)$ with the amount of the pathogen DNA assessed 35 days after sowing, before symptoms of Fusarium wilt had developed (Fig. 5). This indicates that the qPCR protocol was efficient in predicting the resistant/susceptible reaction of the chickpea cultivars to Fusarium wilt in the field. Interestingly, the pathogen could be quantified in 25 to $66.7 \%$ of samples from all remaining chickpea cultivars (except for cvs. BG-212 and WR-315) which are resistant to $F$. oxysporum f. sp. ciceris races 0,5 , and 6 infesting the field plot, although in those samples the $C_{T}$ values were close to the established detection limit of $\mathrm{C}_{\mathrm{T}}=35$ (i.e., 32.6 to 34.0) (Fig. 5).

Quantification of $F$. oxysporum f. sp. ciceris in soil using the q-PCR protocol. Plating soil artificially infested with $F$. oxysporum f. sp. ciceris isolates Foc-7802 and Foc-USA W6-1 and transferred onto VOPA medium yielded average population densities of $4.96 \times 10^{3}$ and $2.98 \times 10^{3} \mathrm{cfu} / \mathrm{g}$ of soil, respectively. Indigenous Fusarium spp. and F. oxysporum f. sp. ciceris population densities in the naturally infested soil from 'Campus de Rabanales' averaged $8.92 \times 10^{2}$ and $44.5 \mathrm{cfu} / \mathrm{g}$ of soil, respec-
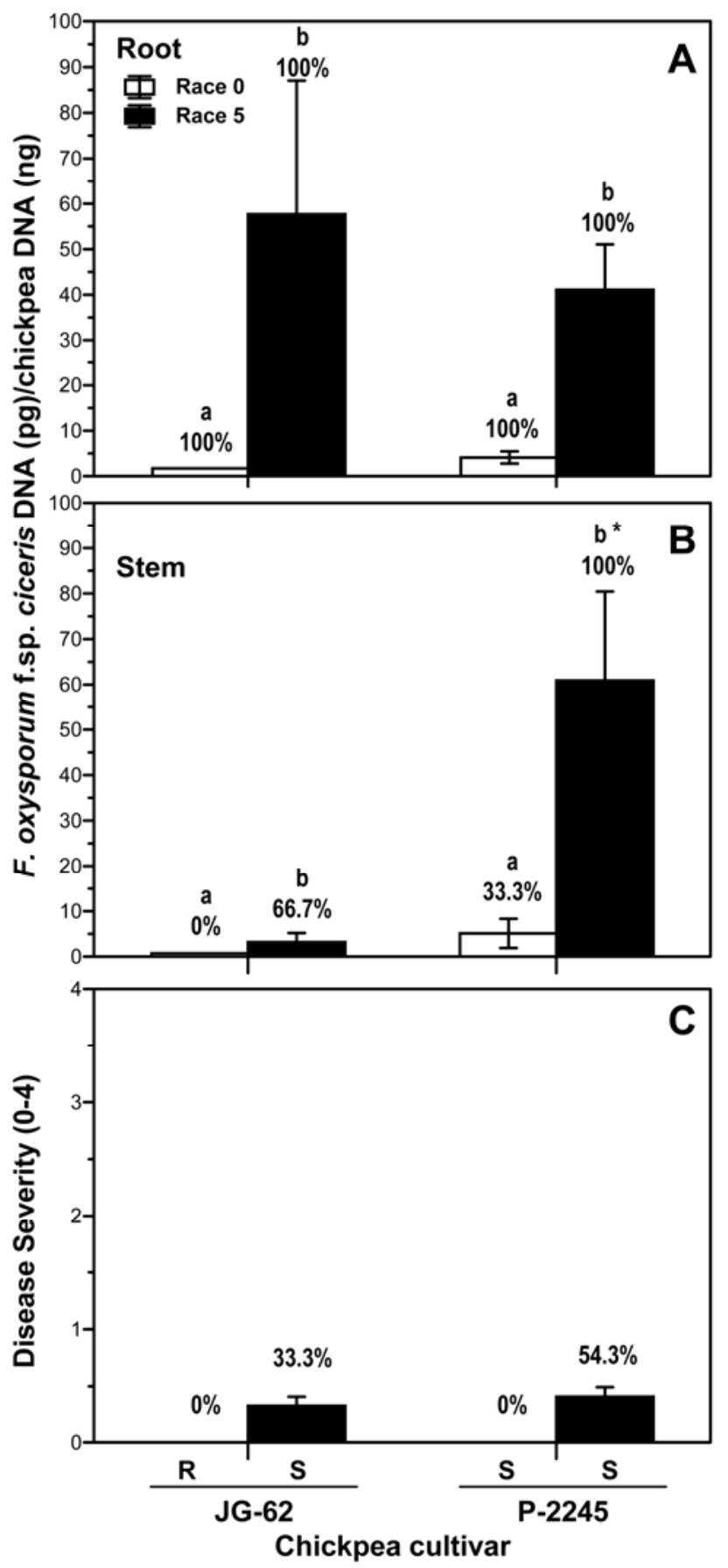

Fig. 4. Amount of Fusarium oxysporum f. sp. ciceris DNA and Fusarium wilt reaction (mean values \pm standard deviation) of chickpea cultivars JG-62 and $\mathrm{P}-2245$ differing in resistance to each of races 0 and 5 of $F$. oxysporum $\mathrm{f}$. sp. ciceris (R: resistant; $\mathrm{S}$ : susceptible). Plants were grown in soil artificially infested with those races under controlled environmental conditions for 15 days. Amount of pathogen DNA in A, roots or $\mathbf{B}$, stems estimated by using a F. oxysporum f. sp. ciceris-specific quantitative polymerase chain reaction (qPCR). Percentage values shown over the bars correspond to number of samples positive for amplification in the q-PCR assay. $\mathbf{C}$, Severity score $(S, 0$ to 4 scale) of disease reactions. Percentages values shown over the bars correspond to the incidence of Fusarium wilt symptomatic plants. Bars with different letters indicate significant $(P<0.05)$ differences between the amounts of each pathogen race detected in the same cultivar. An asterisk (*) indicates significant $(P<0.05)$ differences between cultivars for the same pathogen race. 
tively (Fig. 6). F. oxysporum f. sp. ciceris colonies represented less than 5\% of total Fusarium spp. colonies in that field. In addition to giving rise to lower population density, assaying the soil samples from the naturally infested soil also showed higher variability among replicates compared with those from artificially infested soils.

Use of the q-PCR protocol allowed detection of F. oxysporum $\mathrm{f}$. sp. ciceris DNA in $100 \%$ of samples (six independent DNA extraction replicates) from the artificially infested soil, which reached $692.6 \pm 149.4$ and $10.7 \pm 5.6 \mathrm{pg}$ of DNA/g of dry soil for Foc-7802 and Foc-USA W6-1, respectively (Fig. 6), indicating different survival ability of isolates after storage of the infested soil for 5 months. On the contrary, F. oxysporum f. sp. ciceris DNA could be quantified in $66.7 \%$ of six independent DNA extraction replicates in the naturally infested soil 'Campus de Rabanales'. The amount of $F$. oxysporum f. sp. ciceris DNA in soil was variable, ranging from 2.7 up to $9.4 \mathrm{pg}$ of DNA/g of soil (Fig. 6).

\section{DISCUSSION}

In the present study we developed a real-time q-PCR-based assay using either of two new primer sets that allow for identification and quantification of all pathogenic races of $F$. oxysporum f. sp. ciceris in soil and chickpea tissues. These primers are internal in the sequence amplified by those designed by JiménezGasco and Jiménez-Díaz (22) and used in a conventional PCR protocol with a detection limit of $0.1 \mathrm{ng}$, using DNA extracted from mycelia of $F$. oxysporum f. sp. ciceris. Our results demonstrated that the two new primer sets unambiguously differentiate $F$. oxysporum f. sp. ciceris from other formae speciales, nonpathogenic isolates of $F$. oxysporum and other Fusarium spp., reproducing the specificity described by JiménezGasco and Jiménez-Díaz (22), but as a difference, the new primer sets allow pathogen quantification in planta and soil. Thus, this newly developed q-PCR protocol should be particularly useful for discriminating $F$. oxysporum f. sp. ciceris from nonpathogenic $F$.

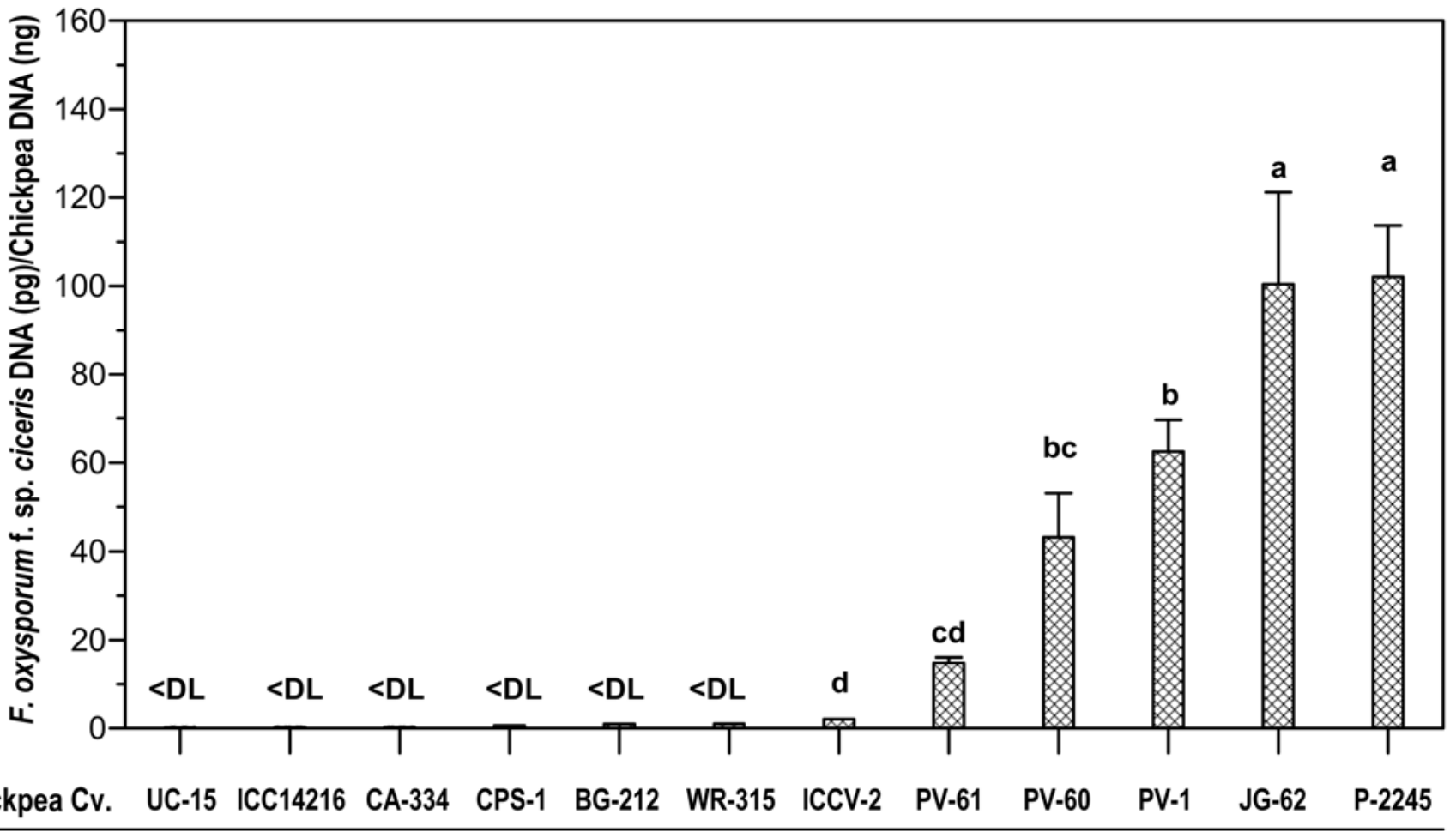

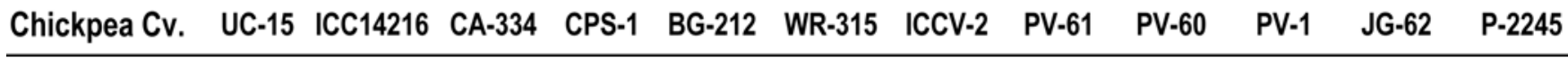

\begin{tabular}{|c|c|c|c|c|c|c|c|c|c|c|c|c|}
\hline \multicolumn{13}{|l|}{ Reaction to: } \\
\hline Race 0 & $\mathrm{R}$ & $\mathrm{R}$ & $\mathrm{R}$ & $\mathrm{R}$ & $\mathrm{R}$ & $\mathrm{R}$ & $\mathrm{R}$ & $M$ & M & $S$ & $\mathrm{R}$ & $S$ \\
\hline Race 5 & $\mathrm{R}$ & $\mathrm{R}$ & $\mathrm{R}$ & M & $\mathrm{R}$ & $R$ & $S$ & M & $S$ & $\mathrm{R}$ & $S$ & $S$ \\
\hline Race 6 & $\mathrm{R}$ & $\mathrm{R}$ & $R$ & $\mathrm{R}$ & $\mathrm{R}$ & $R$ & $M$ & $S$ & S & $\mathrm{R} / \mathrm{M}$ & S & $S$ \\
\hline $\begin{array}{l}\text { Final Disease } \\
\text { Incidence (\%): }\end{array}$ & 0 & 0 & 0 & 0 & 0 & 0 & 3.5 & 50.5 & 64.2 & 86.9 & 92.4 & 99.3 \\
\hline $\begin{array}{l}\text { Samples + } \\
\text { by q-PCR }(\%) \text { : }\end{array}$ & 25.0 & 33.3 & 66.7 & 41.7 & 0.0 & 0.0 & 83.3 & 100 & 100 & 100 & 100 & 100 \\
\hline $\mathrm{C}_{\mathrm{T}}$ range: & 34.0 & 32.6 & 33.4 & 33.7 & 35.0 & 35.0 & 29.4 & 28.8 & 26.1 & 26.0 & 26.1 & 24.8 \\
\hline & 35.0 & 35.0 & 35.0 & 35.0 & nd & nd & 35.0 & 30.9 & 28.4 & 29.0 & 32.8 & 27.0 \\
\hline
\end{tabular}

Fig. 5. Amount of Fusarium oxysporum f. sp. ciceris DNA (mean values \pm standard deviation) in roots of 12 chickpea cultivars estimated by using a $F$. oxysporum f. sp. ciceris-specific quantitative polymerase chain reaction (q-PCR) protocol at 35 days after sowing (DAS) in a field plot naturally infested with races 0,5 , and 6 of F. oxysporum f. sp. ciceris. Disease reaction to races 0, 5, and 6 (R: resistant; M: moderately susceptible; and S: susceptible), final disease incidence estimated as the percentage of dead plants at 85 DAS, percentage of samples that could be amplified by the q-PCR protocol, and range of cycle threshold $\left(\mathrm{C}_{\mathrm{T}}\right)$ values obtained in the q-PCR assay, are indicated for each cultivar. Bars with different letters indicate significant $(P<0.05)$ differences in the amount of $F$. oxysporum $\mathrm{f}$. sp. ciceris DNA detected by the q-PCR assay. $\mathrm{nd}=$ not detected; samples with $\mathrm{C}_{\mathrm{T}}$ values over the detection limit (DL) $\left(\mathrm{C}_{\mathrm{T}} \geq 35\right)$. 
oxysporum and from all other Fusarium spp. with morphology similar to $F$. oxysporum. Such Fusarium spp. are frequently isolated from plants showing wilting-like symptoms due to infection by certain virus species or affected by abiotic stresses, or even from plants severely affected by Fusarium wilt $(2,25,56$; R. M. Jiménez-Díaz and B. B. Landa, unpublished data).

The sensitivity of our assay was not affected by the source of the DNA used as reported by other researchers using conventional- or q-PCR protocols for the detection of formae speciales of $F$. oxysporum from plants or soil $(11,27,37,47)$. We were readily able to detect and quantify $F$. oxysporum $\mathrm{f}$. sp. ciceris in naturally infected chickpea roots and stems and naturally infested soil. The amplification efficiency, sensitivity and reproducibility of our tests were not influenced by presence of other sources of nontarget DNA. We were able to detect down to $1 \mathrm{pg}$ of $F$. oxysporum f. sp. ciceris DNA from both soil and plant tissues without loosing accuracy. Similar detection limits were found when using q-PCR protocols for the detection of other vascular infecting fungi, including Fusarium spp. or other formae speciales of $F$. oxysporum in planta and soil $(4,9,36,46,47,49,58-$ $60)$. However, in those studies the potential interference of background DNA from host plant tissues or soil in the q-PCR assay was either not reported $(9,46,47,59)$ or if considered, showed no effect $(4,36,58,60)$ or in one instance reduced the efficiency, accuracy and detection limit of amplifications (49). In all of the above referenced protocols the target sequence of the qPCR was within the ribosomal DNA that occurs in multicopies (24). The SCAR-specific target sequence (AF492451) we use occurs as a single copy within the genome of $F$. oxysporum $\mathrm{f}$. sp. ciceris (22).

Currently, available techniques for quantification of $F$. oxysporum f. sp. ciceris utilize soil dilution plating on semiselective media allow only for the assessment of $F$. oxysporum isolates without discriminating $F$. oxysporum f. sp. ciceris from nonpathogenic $F$. oxysporum isolates. In addition, $F$. oxysporum identification from those plates is tedious and requires detailed microscopic observations of diagnostic morphological traits. Then, the specific primers developed in this study or that from Jiménez-Gasco and Jiménez-Díaz (22) can be used to identify $F$. oxysporum f. sp. ciceris from those $F$. oxysporum developed on plates using conventional- or q-PCR protocols developed here; but the whole process will be time consuming.

The q-PCR protocol described here can also accurately identify and quantify $F$. oxysporum f. sp. ciceris populations in soil. Our results indicate that about $45 \mathrm{cfu}$ of $F$. oxysporum $\mathrm{f}$. sp. ciceris/g of dry soil can be detected and that this corresponds to about $4 \mathrm{pg}$ of pathogen DNA/g of soil. The $50 \mathrm{cfu} / \mathrm{g}$ of dry soil was the inoculum density of a mixture of $F$. oxysporum $\mathrm{f}$. sp. ciceris races $(0,5$, and 6$)$ that was present in the soil sample tested (28), and this amount was able to cause $100 \%$ mortality in highly susceptible chickpea cultivars (Fig. 5). García-Pedrajas et al. (11) experienced difficulties when trying to detect $F$. oxysporum f. sp. ciceris from the same experimental field plot soil using a nestedPCR protocol that amplifies a band specific to the isolates belonging to the wilting pathotype of this pathogen. The authors attributed the poor consistency of amplifications to the high clay content of this soil. In this regard, the use of the MoBio Ultraclean soil DNA isolation kit (MoBio Laboratories Inc., Carlsbad, CA) in our study may have helped to increase the consistency and sensitivity of amplification.

A possible limitation shared by the developed q-PCR protocol with all molecular detection and quantification methods based on DNA amplification is its inability to distinguish viable from non viable or dead fungal propagules. However, DNA from dead cells in soils should be degraded fairly rapidly due to high microbial activity, and it can be speculated that DNA amplification from dead propagules might be of lesser importance, if any $(15,35)$. Taken alone, data on concentration of pathogen DNA in soil may be useful only for relative comparisons across soil samples, but it does not necessarily reflect the viability or pathogen inoculum potential. Additionally, although the incidence and severity of Fusarium wilt of chickpea epidemics depend greatly on inoculum

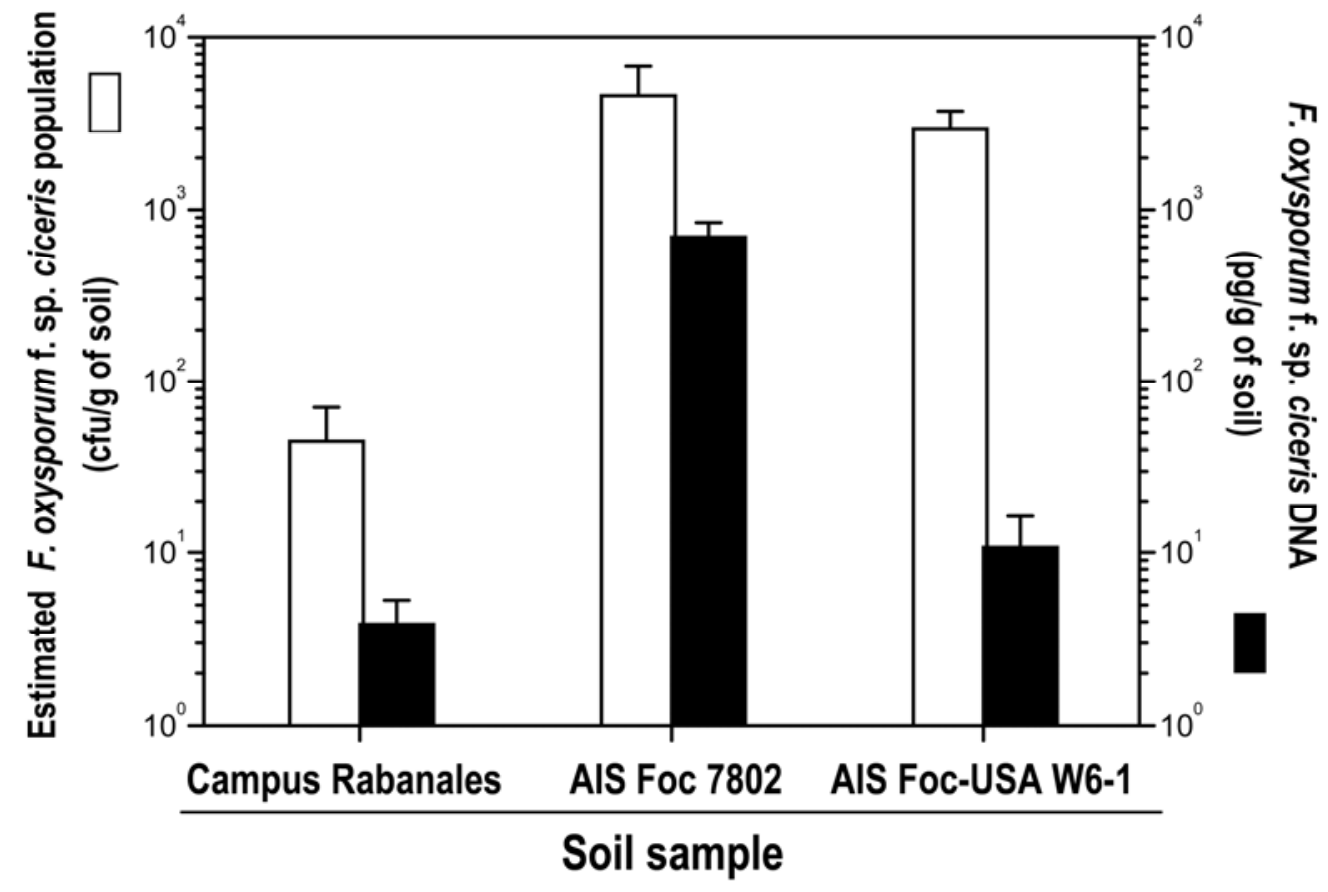

Fig. 6. Fusarium oxysporum f. sp. ciceris DNA concentrations estimated by the F. oxysporum f. sp. ciceris-specific quantitative polymerase chain reaction (q-PCR) protocol compared to numbers of colony forming units (cfu) of $F$. oxysporum f. sp. ciceris per gram of dry soil in an artificially infested soil (AIS) and the naturally infested soil 'Campus de Rabanales'. The artificially infested soil was inoculated with a conidial suspension of Foc-7802 and Foc-USA W6-1 to reach approximately $2 \times 10^{3}$ conidia per gram of soil, air dried, and kept at $5^{\circ} \mathrm{C}$ for 5 months before estimating the inoculum concentration. The numbers of cfu of $F$. oxysporum f. sp. ciceris were estimated by dilution plating in Fusarium-semiselective medium and subsequent analysis of $10 \%$ of $F$. oxysporum colonies by means of an F. oxysporum f. sp. ciceris-specific-PCR assay using primer set FOCP1. 
density of the pathogen, they may also be influenced by local environmental conditions, virulence of the prevailing race of the pathogen, susceptibility of chickpea cultivars, and their interactions $(30,31,33,39-42)$. Even with those limitations, the q-PCR protocol described for quantifying $F$. oxysporum f. sp. ciceris in soil may be a useful tool for studies of the ecology of natural populations of this pathogen in soil, and for surveying the occurrence and distribution of the pathogen in agricultural soils, thereby helping growers to avoid sowing crops in infested fields.

Management of Fusarium wilt of chickpea is difficult to achieve and no single control measure is fully effective. Currently, the use of resistant cultivars appears to be the most practical and economically efficient control measure for management of the disease and is also a key component in IPM programs $(17,20,21)$. Resistant cultivars must be characterized by visual assessment of disease reactions in infested nurseries or pathogenicity tests that are conceptually simple but costly in time, facilities, and resources and, more importantly, the disease responses can be influenced by several environmental factors $(12,20,21,30,31,33,40$ $42,51,56)$. The q-PCR protocol developed in this study provides a rapid, reliable, and reproducible method for the unambiguous characterization of complete resistance of chickpea genotypes irrespective of the races of the pathogen when assessing the ability of the pathogen to reach the stem of the assessed cultivars. Use of the protocol allowed to clearly differentiating susceptible from resistant responses of chickpea genotypes to races of the pathogen by means of the amount of pathogen DNA quantified in root and stem tissues at a time after inoculation in which plants showed none or scarcely discernable symptoms.

Most conventional or q-PCR protocols developed for other formae speciales of $F$. oxysporum were able to detect or quantify the pathogen in roots but not in stems of asymptomatic plants or even of those showing clear wilting symptoms $(3,27,46,60)$. For example, Kelly et al. (27) were able to detect the wilting race 5 of F. oxysporum f. sp. ciceris in the root, but not in the stem, of asymptomatic chickpea cv. P-2245 6 days after inoculation, using a conventional-PCR assay specific for the wilting pathotype of the pathogen. However, according to our results with this same highly compatible interaction the amount of pathogen DNA detected in the stem was higher than that found in the roots, which may indicate the early and fast progression of the pathogen from the root xylem vessels to the stem vessels. Histological examination of vascular tissues of 'JG-62' and 'P-2245' chickpeas infected by F. oxysporum f. sp. ciceris race 5 revealed few hyphae in root xylem vessel but none in stem vessels by 10 days after inoculation, but abundant mycelia occurred in root vessels and to a much lesser extend in stem vessels, 10 days later (19). Comparatively, infection of xylem vessels in the less compatible interaction race $0 /{ }^{\prime} \mathrm{P}-2245^{\prime}$ ' chickpea developed later and to a lower extent than that in the highly compatible race 5/'P-2245' chickpea (19). Nevertheless, the results referenced above might not fully reflect the infection process for all $F$. oxysporum f. sp. ciceris races/chickpea cultivars interactions. A recent, detailed study of the infection process in several of those interactions (race $5 /{ }^{\circ} \mathrm{JG}-$ 62 ' and 'P-2245'; race $0 /{ }^{\circ} \mathrm{P}-2245$ ') using confocal laser microscopy and races of $F$. oxysporum f. sp. ciceris transformed with the ZsGreen fluorescent protein indicates that extensive colonization of stem vascular tissues takes place by 10 days after inoculation (D. Jiménez-Fernández, B. B. Landa, R. M. JiménezDíaz, and J. A. Navas-Cortés, unpublished data). Similar to our results, Zambounis et al. (59) found the amount of genomic DNA of $F$. oxysporum $\mathrm{f}$. sp. vasinfectum in the susceptible cotton $\mathrm{cv}$. Lacta was higher than that in the resistant cv. Emerald. However, for both cultivars, a higher amount of pathogen DNA was detected in hypocotyl tissues compared with root tissues.

In addition to differentiating resistant from susceptible reactions, the developed q-PCR protocol also detected differences in the level of virulence between $F$. oxysporum $\mathrm{f}$. sp. ciceris races 0 and 5 in chickpea cv. P-2245. Thus, the amount of DNA of the highly virulent race 5 detected in chickpea tissues was higher than that of the less virulent race 0. Similar correlations have been reported for other vascular-infecting fungi. Using a conventional SCAR-PCR procedure, Alves-Santos et al. (3) were able to detect only DNA of highly virulent isolates of $F$. oxysporum $\mathrm{f}$. sp. phaseoli in common bean tissues but failed to do so for weakly virulent isolates. Similarly, Mercado-Blanco et al. (38) found higher DNA amounts of the highly virulent defoliating pathotype of Verticillium dahliae in olive tissues compared with those determined for the less virulent, nondefoliating pathotype.

The practical application of the developed q-PCR protocol for Fusarium wilt resistance breeding programs was shown with results from the field experiment. We were able to clearly differentiate highly susceptible from resistant reactions in a collection of 12 chickpea cultivars that grew in a field plot infested with several races of the pathogen based on the amount of $F$. oxysporum $\mathrm{f}$. sp. ciceris DNA infecting the roots. There was a significant correlation between the amount of DNA of $F$. oxysporum $\mathrm{f}$. sp. ciceris quantified in roots from asymptomatic plants early in the crop season and the final incidence of dead plants due to the disease at the end of the growing season. We were also able to quantify $F$. oxysporum f. sp. ciceris DNA in roots of some chickpea cultivars resistant to races 0,5 , and 6 infesting the field soil. This may be explained by the infection and extensive colonization of the root cortex that can occur in incompatible race-cultivar combinations and that have been observed for other formae speciales of $F$. oxysporum, including $F$. oxysporum f. sp. ciceris $(43,44$; D. Jiménez-Fernández, B. B. Landa, R. M. Jiménez-Díaz, and J. A. Navas-Cortés, unpublished data). Additionally, new pathogenic variants of $F$. oxysporum f. sp. ciceris have been found at low frequency in that experimental field plot that could not be characterized into any of the described races of the pathogen (28). As far as we know, this is the first demonstration of the use of a q-PCR protocol for resistance screening in a large number of plant genotypes growing in a Fusarium wiltinfested soil under natural field conditions.

In summary, the possibility of demonstrating absence of the pathogen in symptomless chickpeas, and quantifying $F$. oxysporum f. sp. ciceris in asymptomatic plants or plants mildly affected by Fusarium wilt by means of the q-PCR protocol developed in this study, among other uses, will be of a great interest for Fusarium wilt resistance screening of chickpea germplasm. That will allow to rapidly select breeding lines with putative complete resistance, and purposely select those that may be partially resistant, late wilting, or tolerant, yet carrying traits of agronomic and/or commercial interest. Thus, as a whole, we are confident that the q-PCR protocol developed in this study for the identification and quantification of $F$. oxysporum $\mathrm{f}$. sp. ciceris in chickpea tissues and soil will be of great use for studies aimed to gain better understanding of Fusarium wilt epidemiology, as well as efficient management of the disease through pathogen exclusion, prediction of disease risk potential and disease resistance breeding.

\section{ACKNOWLEDGMENTS}

Financial support for this research was provided by grants AGL200401231 from 'Ministerio de Educación y Ciencia' of Spain and the European Social Fund, AGR580 from 'Consejería de Economía, Innovación y Ciencia', Junta de Andalucía, and an 'Intramural Project' to B. B. Landa from the Spanish National Research Council (CSIC). We thank G. Contreras-Arias (IAS-CSIC) for excellent technical assistance and P. Castillo for critically reading the manuscript prior to submission.

\section{LITERATURE CITED}

1. Adams, P. S. 2006. Data analysis and reporting. Pages 39-62 in: RealTime PCR. M. T. Dorak, ed. Taylor \& Francis, New York. 
2. Alves-Santos, F. M., Benito, E. P., Eslava, A. P., and Díaz-Mínguez, J. M. 1999. Genetic diversity of Fusarium oxysporum strains from common bean fields in Spain. Appl. Environ. Microbiol. 65:3335-3340.

3. Alves-Santos, F. M., Ramos, B., García-Sánchez, M. A., Eslava, A. P., and Díaz-Mínguez, J. M. 2002. A DNA-based procedure for in planta detection of Fusarium oxysporum f. sp. phaseoli. Phytopathology 92:237244.

4. Atallah, Z. K., Bae, J., Jansky, S. H., Rouse, D. I., and Stevenson, W. R. 2007. Multiplex real-time quantitative PCR to detect and quantify Verticillium dahliae colonization in potato lines that differ in response to Verticillium wilt. Phytopathology 97:865-872.

5. Bhatti, M. A., and Kraft, J. M. 1992. Effects of inoculum density and temperature on root rot and wilt of chickpea. Plant Dis. 76:50-54.

6. Bouhot, D., and Rouxel, F. 1971. Technique selective et quantitative d'analyse des Fusarium oxysporum et Fusarium solani dans le sol. Mode d'emploi. Ann. Phytopathol. 3:251-254.

7. Cabrera de la Colina, J., Trapero-Casas, A., and Jiménez-Díaz, R. M. 1985. Races of Fusarium oxysporum f. sp. ciceri in Andalucía, southern Spain. Int. Chickpea Newsl. 13:24-26.

8. Dolar, F. S. 1997. Determination of the races of Fusarium oxysporum $\mathrm{f}$. sp. ciceris in Ankara province. Turkey. J. Turk. Phytopathol. 26:11-15.

9. Filion, M., St. Arnaud, M., and Jabaji-Hare, S. H. 2003. Quantification of Fusarium solani f. sp. phaseoli in mycorrhizal bean plants and surrounding mycorrhizosphere soil using real-time polymerase chain reaction and direct isolations on selective media. Phytopathology 93:229-235.

10. Food and Agriculture Organization of the United Nations Statistical Database (FAOSTAT). 2009. FAOSTAT production statistics of crops. Available online at http://faostat.fao.org/site/567/default.aspx\#ancor.

11. García-Pedrajas, M. D., Bainbridge, B. W., Heale, J. B., Pérez-Artés, E., and Jiménez Díaz, R. M. 1999. A simple PCR-based method for the detection of the chickpea-wilt pathogen Fusarium oxysporum f. sp. ciceris in artificial and natural soils. Eur. J. Plant Pathol. 105:251-259.

12. Gupta, O., Kotasthane, S. R., and Khare, M. N. 1987. Factors influencing epidemiology of vascular wilt of chickpea. Proc. Natl. Acad. Sci. India 57:86-91

13. Halila, M. H., and Strange, R. N. 1996. Identification of the causal agent of wilt of chickpea in Tunisia as Fusarium oxysporum $\mathrm{f}$. sp. ciceri race 0. Phytopathol. Mediterr. 35:67-74.

14. Haware, M. P., and Nene, Y. L. 1982. Races of Fusarium oxysporum f. sp. ciceri. Plant Dis. 66:809-810.

15. Herdina, K., Neate, S., Jabaji-Hare, S., and Ophel-Keller, K. 2004. Persistence of DNA of Gaeumannomyces graminis var. tritici in soil as measured by a DNA based assay. FEMS Microbiol. Ecol. 47:143-152.

16. Higuchi, R., Fockler, C., Dollinger, G., and Watson, R. 1993. Kinetic PCR analysis: Real-time monitoring of DNA amplification reactions. Biotechnology 11:1026-1030.

17. Jalali, B. L., and Chand, H. 1992. Chickpea wilt. Pages 429-444 in: Plant Diseases of International Importance. Vol. I. Diseases of Cereals and Pulses. U. S. Singh, A. N. Mukhopadhayay, J. Kumar, and H. S. Chaube, eds. Prentice Hall, Englewood Cliffs, NJ.

18. Jiménez-Díaz, R. M., Alcalá-Jiménez, A. R., Hervás, A., and TraperoCasas, J. L. 1993. Pathogenic variability and host resistance in the Fusarium oxysporum f. sp. ciceris/Cicer arietinum pathosystem. Pages 87-94 in: Proc. Eur. Semin. Fusarium Mycotoxins, Taxonomy, Pathogenicity and Host Resistance, 3rd. Hodowla Róslin Aklimatyzacja i Nasiennictwo. Plant Breeding and Acclimatization Institute, Radzikóv, Poland.

19. Jiménez-Díaz, R. M., Basallote-Ureba, M. J., and Rapoport, H. 1989. Colonization and pathogenesis in chickpea infected by races of Fusarium oxysporum f. sp. ciceri. Pages 113-121 in: Vascular Wilt Diseases of Plants. E. C. Tjamos and C. H. Beckman, eds. NATO ASI Series H Vol 28. Heidelberg, Springer-Verlag, Germany.

20. Jiménez-Díaz, R. M., Crinó, P., Halila, M. H., Mosconi, C., and TraperoCasas, A. 1993. Screening for resistance to Fusarium wilt and Ascochyta blight in chickpea. Pages 77-96 in: Breeding for Stress Tolerance in CoolSeason Food Legumes. K. B. Singh and M. C. Saxena, eds. John Wiley and Sons, Chichester, England.

21. Jiménez-Díaz, R. M., Singh, K. B., Trapero-Casas, A., and Trapero-Casas, J. L. 1991. Resistance in kabuli chickpeas to Fusarium wilt. Plant Dis. 75:914-918.

22. Jiménez-Gasco, M. M., and Jiménez-Díaz, R. M. 2003. Development of a specific polymerase chain reaction based assay for the identification of Fusarium oxysporum $\mathrm{f}$. sp. ciceris and its pathogenic races 0, 1A, 5, and 6. Phytopathology 93:200-209.

23. Jiménez-Gasco, M. M., Pérez-Artés, E., and Jiménez-Díaz, R. M. 2001. Identification of pathogenic races $0,1 \mathrm{~B} / \mathrm{C}, 5$, and 6 of Fusarium oxysporum f. sp. ciceris with random amplified polymorphic DNA (RAPD). Eur. J. Plant Pathol. 107:237-248.

24. Judelson, H. S., and Randall, T. A. 1998. Families of repeated DNA in the oomycete Phytophthora infestans and their distribution within the genus.
Genome 41:605-615.

25. Kaiser, W. J., Klein, R. E., Larsen, R. C., and Wyatt, S. D. 1993. Chickpea wilt incited by pea streak carlavirus. Plant Dis. 77:922-926.

26. Kelly, A. G., Alcalá-Jiménez, A. R., Bainbridge, B. W., Heale, J. B., Pérez-Artés, E., and Jiménez-Díaz, R. M. 1994. Use of genetic fingerprinting and random amplified polymorphic DNA to characterize pathotypes of Fusarium oxysporum f. sp. ciceris infecting chickpea. Phytopathology 84:1293-1298.

27. Kelly, A. G., Bainbridge, B. W., Heale, J. B., Pérez-Artés, E., and Jiménez-Díaz, R. M. 1998. In planta-polymerase-chain-reaction detection of the wilt-inducing pathotype of Fusarium oxysporum f. sp. ciceris in chickpea (Cicer arietinum L.). Physiol. Mol. Plant Pathol. 52:397-409.

28. Landa, B. B., Jiménez-Gasco, M. M., and Jiménez-Díaz, R. M. 2009. Influence of disease resistant management strategies on genetic and pathogenic diversity in plant pathogen populations: Fusarium wilt of chickpea, a case study. IOBC/WPRS Bull. 42:119-122.

29. Landa, B. B., Montes-Borrego, M. Muñoz-Ledesma, F. J., and JiménezDíaz, R. M. 2007. Phylogenetic analysis of downy mildew pathogens of opium poppy and PCR-based in planta and seed detection of Peronospora arborescens. Phytopathology 97:1380-1390.

30. Landa, B. B., Navas-Cortés, J. A., Hervás, A., and Jiménez-Díaz, R. M. 2001. Influence of temperature and inoculum density of Fusarium oxysporum f. sp. ciceris on suppression of Fusarium wilt of chickpea by rhizosphere bacteria. Phytopathology 91:807-816.

31. Landa, B. B., Navas-Cortés, J. A., and Jiménez-Díaz, R. M. 2004. Integrated management of Fusarium wilt of chickpea with sowing date, host resistance and biological control. Phytopathology 94:946-960.

32. Landa, B. B., Navas-Cortés, J. A., and Jiménez-Díaz, R. M. 2004. Influence of temperature on plant-rhizobacteria interactions related to biocontrol potential for suppression of Fusarium wilt of chickpea. Plant Pathol. 53:341-352.

33. Landa, B. B., Navas-Cortés, J. A., Jiménez-Gasco, M. M., Katan, J., Retig, B., and Jiménez-Díaz, R. M. 2006. Temperature response of chickpea cultivars to races of Fusarium oxysporum f. sp. ciceris, causal agent of Fusarium wilt. Plant Dis. 90:365-374.

34. Leslie, J. F., and Summerell, B. A. 2006. The Fusarium Laboratory Manual. Blackwell Publishing Ltd., Oxford.

35. Lievens, B., Brouwer, M., Vanachter, A. C. R. C., Cammue, B. P. A., and Thomma, B. P. H. J. 2006. Real-time PCR for detection and quantification of fungal and oomycete tomato pathogens in plant and soil samples. Plant Sci. 171:155-165.

36. Lievens, B., Claes, L., Vakalounakis, D. J., Vanachter, A. C. R. C., and Thomma, B. P. H. J. 2007. A robust identification and detection assay to discriminate the cucumber pathogens Fusarium oxysporum f. sp. cucumerinum and f. sp. radicis-cucumerinum. Environ. Microbiol. 9:2145-2161

37. Mbofung, G. C. Y., and Pryor, B. M. 2010. A PCR-based assay for detection of Fusarium oxysporum f. sp. lactucae in lettuce seed. Plant Dis. 94:860-866

38. Mercado-Blanco, J., Collado-Romero, M., Parrilla-Araujo, S., RodríguezJurado, D., and Jiménez-Díaz, R. M. 2003. Quantitative monitoring of colonization of olive genotypes by Verticillium dahliae pathotypes with real-time polymerase chain reaction. Physiol. Mol. Plant Pathol. 63:91105.

39. Navas-Cortés, J. A., Alcalá-Jiménez, A. R., Hau, B., and Jiménez-Díaz, R. M. 2000. Influence of inoculum density of races 0 and 5 of Fusarium oxysporum f. sp. ciceris on development of Fusarium wilt in chickpea cultivars. Eur. J. Plant Pathol. 106:135-146.

40. Navas-Cortés, J. A., Hau, B., and Jiménez-Díaz, R. M. 1998. Effect of sowing date, host cultivar, and race of Fusarium oxysporum f. sp. ciceris on development of Fusarium wilt of chickpea. Phytopathology 88:13381346.

41. Navas-Cortés, J. A., Hau, B., and Jiménez-Díaz, R. M. 2000. Yield loss in chickpeas in relation to development of Fusarium wilt epidemics. Phytopathology 90:1269-1278.

42. Navas-Cortés, J. A., Landa, B. B., Méndez-Rodríguez, M. A., and Jiménez-Díaz, R. M. 2007. Quantitative modeling of the effects of temperature and inoculum density of Fusarium oxysporum f. sp. ciceris races 0 and 5 on the development of Fusarium wilt in chickpea cultivars. Phytopathology 97:564-573.

43. Olivain, C., Humbert, C., Nahalkova, J., Fatehi, J., L'Haridon, F., and Alabouvette, C. 2006. Colonization of tomato root by pathogenic and nonpathogenic Fusarium oxysporum strains inoculated together and separately into the soil. Appl. Environ. Microbiol. 72:1523-1531.

44. Olivain, C., Trouvelot, S., Binet, M.-N., Cordier, C., Pugin, A., and Alabouvette, C. 2003. Colonization of flax roots and early physiological responses of flax cells inoculated with pathogenic and nonpathogenic strains of Fusarium oxysporum. Appl. Environ. Microbiol. 69:5453-5462.

45. Pande, S., Krishna Kishore, G., Upadhyaya, H. D., and Narayana-Rao, J. 2006. Identification of sources of multiple disease resistance in mini-core 
collection of chickpea. Plant Dis. 90:1214-1218

46. Pasquali, M., Marena, L., Fiora, E., Piatti, P., Gullino, M. L., and Garibaldi, A. 2004. Real-time polymerase chain reaction for identification of a highly pathogenic group of Fusarium oxysporum f. sp. chrysanthemi on Argyranthemum frutescens L. J. Plant Pathol. 86:53-59.

47. Pasquali, M., Piatti, P., Gullino, M. L., and Garibaldi, A. 2006. Development of a real-time polymerase chain reaction for the detection of Fusarium oxysporum f. sp. basilici from basil seed and roots. J. Phytopathol. 154:632-636.

48. Schaad, N. W., Frederick, R. D., Shaw, J., Schneider, W. L., Hickson, R., Petrillo, M. D., and Luster, D. G. 2003. Advances in molecular-based diagnostics in meeting crop biosecurity and phytosanitary issues. Annu. Rev. Phytopathol. 41:305-324.

49. Schena, L., Hughes, K. J. D., and Cooke, D. E. L. 2006. Detection and quantification of Phytophthora ramorum, $P$. kernoviae, $P$. citricola and $P$. quercina in symptomatic leaves by multiplex real-time PCR. Mol. Plant Pathol. 7:365-379.

50. Schena, L., Nigro, F., Ippolito, A., and Gallitelli, D. 2004. Real-time quantitative PCR: A new technology to detect and study phytopathogenic and antagonistic fungi. Eur. J. Plant Pathol. 110:893-908.

51. Sharma, K. D., Chen, W., and Muehlbauer, F. J. 2005. Genetics of chickpea resistance to five races of Fusarium wilt and a concise set of race differentials for Fusarium oxysporum f. sp. ciceris. Plant Dis. 89:385-390.

52. Sharma, K. D., and Muehlbauer, F. J. 2007. Fusarium wilt of chickpea: Physiological specialization, genetics of resistance and resistance gene tagging. Euphytica 157:1-14.
53. Shehabu, M., Ahmed, S., and Sakhuja, K. 2008. Pathogenic variability in Ethiopian isolates of Fusarium oxysporum f. sp. ciceris and reaction of chickpea improved varieties to the isolates. Int. J. Pest Manag. 54:143149.

54. Singh, K. B., and Saxena, M. C. 1996. Winter chickpea in Mediterraneantype environments. International Center for Agricultural research in Dry Areas. Aleppo, Syria.

55. Sugha, S. K., Kapoor, S. K., and Singh, B. M. 1994. Factors influencing Fusarium wilt of chickpea (Cicer arietinum L.). Indian J. Mycol. Plant Pathol. 24:97-102.

56. Trapero-Casas, A., and Jiménez-Díaz, R. M. 1985. Fungal wilt and root rot diseases of chickpea in southern Spain. Phytopathology 75:1146-1151.

57. Vaerman, J. L., Sausssoy, P., and Ingargiola, I. 2004. Evaluation of realtime PCR data. J. Biol. Regul. Homeost. Agents 18:212-214.

58. Valsesia, G., Gobbin, D., Patocchi, A., Vecchione, A., Pertot, I., and Gessler, C. 2005. Development of a high-throughput method for quantification of Plasmopara viticola DNA in grapevine leaves by means of quantitative real-time polymerase chain reaction. Phytopathology 95:672-678.

59. Zambounis, A. G., Paplomatas, E., and Tsaftaris, A. S. 2007. Intergenic spacer-RFLP analysis and direct quantification of Australian Fusarium oxysporum f. sp. vasinfectum isolates from soil and infected cotton tissues. Plant Dis. 91:1564-1573.

60. Zhang, Z., Zhang, J., Wang, Y., and Zheng, X. 2005. Molecular detection of Fusarium oxysporum f. sp. niveum and Mycosphaerella melonis in infected plant tissues and soil. FEMS Microbiol. Lett. 249:39-47. 